\title{
Holocene climate variability in the winter rainfall zone of South Africa
}

\author{
S. Weldeab ${ }^{1}$, J.-B. W. Stuut ${ }^{2,3}$, R. R. Schneider ${ }^{4}$, and W. Siebel ${ }^{5}$ \\ ${ }^{1}$ Department of Earth Science, University of California, Santa Barbara, CA 93106-9630, USA \\ ${ }^{2}$ NIOZ, Royal Netherlands Institute for Sea Research, Texel, the Netherlands \\ ${ }^{3}$ MARUM, Center for Marine Environmental Sciences, University of Bremen, Bremen, Germany \\ ${ }^{4}$ Institute of Geosciences, University of Kiel, Kiel, Germany \\ ${ }^{5}$ Department of Geosciences, University of Tübingen, Tübingen, Germany
}

Correspondence to: S. Weldeab (weldeab@geol.ucsb.edu)

Received: 11 March 2013 - Published in Clim. Past Discuss.: 7 May 2013

Revised: 1 August 2013 - Accepted: 27 August 2013 - Published: 22 October 2013

\begin{abstract}
We established a multi-proxy time series comprising analyses of major elements in bulk sediments, $\mathrm{Sr}$ and $\mathrm{Nd}$ isotopes, grain size of terrigenous fraction, and $\delta^{18} \mathrm{O}$ and $\delta^{13} \mathrm{C}$ in tests of Neogloboquadrina pachyderma (sinistral) from a marine sediment sequence recovered off the Orange River. The records reveal coherent patterns of variability that reflect changes in wind strength, precipitation over the river catchments, and upwelling of cold and nutrient-rich coastal waters off western South Africa. The wettest episode of the Holocene in the winter rainfall zone (WRZ) of South Africa occurred during the "Little Ice Age" (700-100 cal years BP) most likely in response to a northward shift of the austral westerlies. Wet phases and strengthened coastal water upwellings are companied by a decrease of Agulhas water leakage into the South Atlantic and a reduced dust incursion over Antarctica, as indicated in previous studies. A continuous aridification trend in the WRZ and a weakening of the southern Benguela Upwelling System (BUS) between 9000 and 5500 cal years BP parallel with increase of dust deposition over Antarctica and an enhanced leakage of warm Agulhas water into the eastern South Atlantic. The temporal relationship between precipitation changes in the WRZ, the thermal state of the coastal surface water, and leakage of warm water in the South Atlantic, and variation of dust incursion over Antarctica suggests a causal link that most likely was related to latitudinal shifts of the Southern Hemisphere westerlies. Our results of the mid-Holocene time interval may serve as an analogue to a possible long-term consequence of the current and future southward shift of the westerlies. Further-
\end{abstract}

more, warming of the coastal surface water as a result of warm Agulhas water incursion into the southern BUS may affect coastal fog formation.

\section{Introduction}

Instrumental and modeling data indicate that the southward displacement of austral westerlies and increased amount of leakage of warm, saline Agulhas water into the South Atlantic may have a negative impact on the winter rainfall zone (WRZ) of South Africa and weaken the southern Benguela Upwelling System (BUS; Biastoch et al., 2008, 2009; Lutjeharms et al., 2001; MacKellar et al., 2007; HardmanMountford et al., 2003). Paleoclimate records can provide insights that may help to assess the long-term impact of such ocean-atmosphere changes. However, conventional terrestrial climate archives such as lake and cave deposits are sparse in arid and semi-arid regions, limiting a dense spatiotemporal coverage and multi-proxy approach of climate reconstructions, a prerequisite to gaining a better understanding of regional climate variability and its link to largescale atmosphere-ocean climate coupling. The coastal area of southwestern Africa is located in the semi-arid ecosystem (MacKellar et al., 2007, and reference therein), and our knowledge of past climate variability so far has relied on a few low-resolved proxy records. The emergence of new climate archives and proxies such as hyrax dung and optically stimulated luminescence dating have led to relatively 
more spatio-temporal coverage of paleoclimate information for southwestern Africa (Chase et al., 2011, 2009; Chase and Thomas, 2006, 2007; Meadows et al., 2010; Meadows and Sugden, 1991; Scott and Woodborne, 2007a, b). These records, along with the most recent high-resolution climate reconstruction of the late Holocene from the western coastal area of South Africa (Benito et al., 2011; Stager et al., 2012), reveal that the WRZ of South Africa was very sensitive to centennial- and millennial-scale climate oscillations during the Holocene epoch. Notwithstanding the increasing number of paleo-records, the regional significance of and temporal correlation between the local climate signals and their link to surface water conditions of the adjacent ocean remain uncertain. Our study adds to the emerging pattern of past climate variability in southwestern Africa by providing a spatially integrated record of terrestrial climate changes and its link to adjacent coastal water conditions that allow us to infer possible climatic links to the Southern Hemisphere westerlies and the leakage of warm Agulhas water into the eastern South Atlantic.

\section{Regional setting}

The WRZ of southwestern Africa stretches along the eastern South Atlantic coastal region from southwestern Namibia to Cape Agulhas and extends inland to the western margin of the Great Escarpment (Chase and Meadows, 2007; MacKellar et al., 2007) (Fig. 1). The WRZ receives $>65 \%$ of the annual rainfall during the austral winter, and consists of arid and semi-arid regions including the southern Namib Desert and Namaqualand of South Africa (Chase and Meadows, 2007; MacKellar et al., 2007; Cowling et al., 1999). Along the coastal area, precipitation varies between $50 \mathrm{~mm}$ and $350 \mathrm{~mm}$ per year with marked local patterns (MacKellar et al., 2007).

Namaqualand borders on dynamic coastal waters that are marked by inner-shelf upwellings that prevail throughout the year with enhanced intensity during the austral winter (Hardman-Mountford et al., 2003). This upwelling area constitutes the southern BUS whose intensity is driven by the strength and position of the southeasterly trade winds (Hardman-Mountford et al., 2003). On average, sea surface temperature (SST) and salinity account for $13.5^{\circ} \mathrm{C}$ and 35 practical salinity unit (psu) during the austral winter and $16.9^{\circ} \mathrm{C}$ and $34.9 \mathrm{psu}$ during the austral summer (Locarnini et al., 2010). Within the southern BUS, localized cells of strong upwelling exist, including the Namaqua cell (Hardman-Mountford et al., 2003) from which the sediment core GeoB8332-4 was recovered. On interannual and interdecadal time scales, a weakening of the southern BUS occurs in response to a southward shift of the austral westerlies that allows the intrusion of warm Agulhas surface water into the eastern South Atlantic (Hardman-Mountford et al., 2003; Biastoch et al., 2009).
We focus on a marine sediment sequence recovered from the mudbelt whose detrital composition is determined by fluvial and eolian sediment inputs from the Orange River, Namaqualand, and the Namib Desert. The mudbelt is a prominent Holocene sediment package that covers a narrow strip along the inner-shelf between the Kunene River in the northwest and St. Helena Bay in the southeast (Compton et al., 2009, 2010; Herbert and Compton, 2007; Meadows et al., 2002; Rogers and Rau, 2006).

The Orange River presents the most dominant sediment source for the mudbelt, with a catchment area of $973000 \mathrm{~km}^{2}$, runoff of $11 \mathrm{~km}^{3} \mathrm{yr}^{-1}$, and 60 million metric

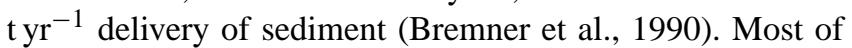
the Orange River runoff and suspended sediment comes from the easternmost catchment that receives an annual rainfall between $500 \mathrm{~mm}$ and $>750 \mathrm{~mm}$ during austral summer (Compton et al., 2010) (Fig. 1). Detailed mineralogical, chemical, and isotopic evidence indicates that the suspended sediments of the Orange River mainly originate from the upper part of Karoo Supergroup (Palaeozoic to Mesozoic deposits) (Compton and Maake, 2007; de Villiers et al., 2000). The Drakensberg Plateau, which is composed of flood basalt intersected by dolerite dykes/sills, receives high precipitation $\left(>750 \mathrm{~mm} \mathrm{yr}^{-1}\right.$ ) but contributes relatively small amounts to the total sediment load of the Orange River (Compton and Maake, 2007; de Villiers et al., 2000). Once it enters the Atlantic Ocean, waves and undercurrent distribute the massive sediment load of the Orange River. The sand fraction is swept northward by wave-driven littoral drifts (Meadows et al., 2002; Rogers and Rau, 2006). Northwesterly undercurrents distribute clayey-silty material to the southeast of the Orange River mouth, with decreasing grain size toward the southeastern end of the mudbelt (Meadows et al., 2002; Rogers and Rau, 2006).

Ephemeral (Holgat and Buffels) and perennial (Olifants and Berg) rivers drain the western coastal area of South Africa (Fig. 1) that consists of Precambrian sedimentary rocks ( $>2.5$ billion years $(\mathrm{Ga})$ old) and intrusions of $1 \mathrm{Ga}$ granite and gneiss (Cowling et al., 1999). With a total catchment area of $\sim 65200 \mathrm{~km}^{2}$ and an arid/semi-arid climate, the overall sediment contribution of the local rivers to the mudbelt is estimated to be relatively small (a quantitative estimate is not available) as compared to that of the Orange River (Herbert and Compton, 2007; Meadows et al., 2002; Rogers and Rau, 2006). Notable sedimentary imprint of the ephemeral rivers is found in sediment sequences recovered from the immediate vicinity of local river mouths (Mabote, 1997; Rogers and Rau, 2006). The significance of eolian sediment inputs to the mudbelt from dust originating from the Namib Desert and Namaqualand has been recognized by several studies (Mabote, 1997; Rogers and Rau, 2006; Shannon and Anderson, 1982) and is estimated to account for $7-10 \mathrm{~g} \mathrm{~m}^{-2} \mathrm{yr}^{-1}$ of the Orange and Holgat River sediment load (Mahowald et al., 2005). In Namaqualand, the dust is mobilized by the katabatic winds (locally called berg 

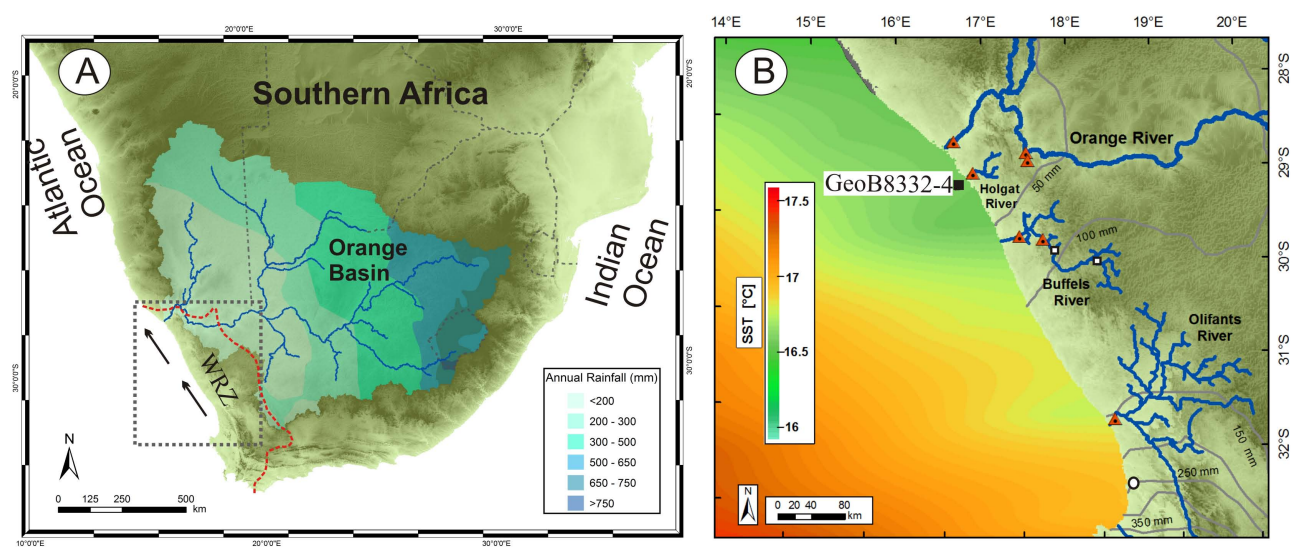

Fig. 1. (A) Map of southern Africa indicating the basin of the Orange River, annual rainfall over the basin (rainfall contour redrawn from Compton et al. (2010)), and the winter rainfall zone (WRZ) delineated by the orange line. Black arrows indicate southeasterly trade winds. Dotted square indicates area whose details is shown Fig. 1b. (B) Coastal area of southwestern Africa showing local rivers, annual precipitation (gray contours), annual sea surface temperature (Locarnini et al., 2010), location of GeoB8332-4 (black square), and riverine sediment samples used for $\mathrm{Sr}$ and $\mathrm{Nd}$ isotope analyses (orange triangles). Shown is also the approximate location of Lake Verlorenvlei (white circle) (Stager et al., 2012) and paleo-flood investigation on the Buffels River banks (white squares) (Benito et al., 2011).

winds) (Mabote, 1997; Rogers and Rau, 2006; Shannon and Anderson, 1982).

Overall, the complex depositional setting of our core site arises not only due to riverine and dust inputs from proximal and distal catchments within the winter and summer rainfall zones, but also sediment redistribution and sorting by bottom water currents. We employ a multi-proxy approach to shed light on the Holocene climate imprint in the sediment sequence off the Holgat River. We use grain size and element ratio data to reconstruct the variation of riverine and eolian inputs. While the analysis of $\mathrm{Nd}$ and $\mathrm{Sr}$ isotope ratios is used to track changes in the source of riverine and eolian sediments, we use $\delta^{18} \mathrm{O}$ and $\delta^{13} \mathrm{C}$ in the planktonic foraminifera Neogloboquadrina pachyderma to understand the surface conditions of the coastal water.

\section{Material and methods}

Our study focuses on sediment core GeoB8332-4 recovered within the mudbelt $\left(29^{\circ} 07.66^{\prime} \mathrm{S}, 16^{\circ} 39.57^{\prime} \mathrm{E}\right.$, water depth $117 \mathrm{~m}$ ), approximately $10 \mathrm{~km}$ and $57 \mathrm{~km}$ off the Holgat and Orange rivers, respectively (Fig. 1). The down-core measurements are complemented by analysis of sediments collected from riverbeds and suspended sediment of the Orange River and local Holgat, Buffels, and Olifants rivers (Fig. 1). The GeoB8332-4 sediment sequence consists of a monotonous dark greenish-gray mud that is slightly bioturbated and had a strong $\mathrm{H}_{2} \mathrm{~S}$ odor at time of the recovery. Onboard measurements of color reflectance, magnetic susceptibility, porosity, and wet bulk density also show a monotonous trend (Schneider et al., 2003). The GeoB8332-4 core terminates at a sediment depth of $808 \mathrm{~cm}$ with a sediment layer that is rich in gastropod and bivalve shells. Throughout the sediment se-
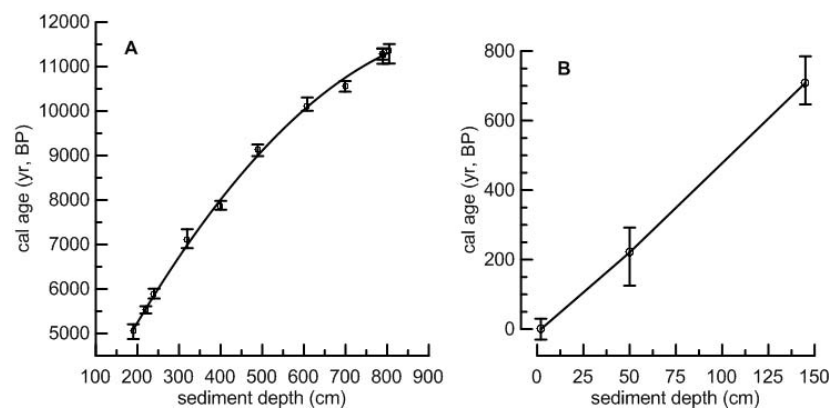

Fig. 2. Calendar age versus GeoB8332-1 sediment depth. Open circles, vertical bars, and lines indicate ${ }^{14} \mathrm{C}$-based age model control points, uncertainty in the age model control points $(2 \sigma)$, and the final age model that is based on polynomial (A) and linear fits (B).

quence, several intact and well-preserved shells of small gastropods and bivalves were found. Due to the low abundance of foraminifera we used gastropod shells for ${ }^{14} \mathrm{C}$ dating.

The age model of GeoB8332-4 sediment is based on 15 radiocarbon datings of small, well-preserved gastropod shells (Nassarius vinctus, J. Compton, personal communication, 2004). Prior to the selection for ${ }^{14} \mathrm{C}$ dating, the gastropod shells were carefully inspected for signs of corrosion and fragmentation that could be indicative of transport by waves and currents. To our best judgment, the gastropods we used for dating are autochthonous. The absence of age reversals in the densely dated sections and replicated measurements support the autochthonous origin of the gastropod samples (Fig. 2 and Table 1). Radiocarbon measurements were conducted at the Leibniz Institute for Radiometric Dating and Isotope Research in Kiel, Germany. The ${ }^{14} \mathrm{C}$ data reveal that the GeoB8332-4 sediment sequence contains a highly 
resolved climate record of the early to middle Holocene (11 500-5000 cal years BP) and the last 700 cal years BP. Unfortunately, a hiatus covers the interval between 5000 and 700 cal years BP. Nonetheless, the late and early-middle Holocene record provides detailed insights into climate variability of southwestern Africa. The ${ }^{14} \mathrm{C}$ data were converted to calendar ages using CALIB software (Stuiver and Reimer, 1993) (version 6.10), Marine data set 2009 (Reimer et al., 2009 ), and $\Delta \mathrm{R}$ of $129 \pm 19 \mathrm{yr}$ reservoir age of the local coastal water (Dewar et al., 2012). The final age model is established using polynomial (11 500-5000 cal years BP) and linear (700-0 cal years BP) equations describing the relationship between sediment depth and calendar ages (Fig. 2).

Prior to the grain size analysis of the terrigenous fraction, we removed the biogenic fraction from GeoB8332-4 sediment samples. Organic matter and carbonate components were removed by adding $10 \mathrm{ml}$ of $\mathrm{H}_{2} \mathrm{O}_{2}(35 \%)$ and $100 \mathrm{~mL}$ $\mathrm{HCl}(1 \%)$ to $750 \mathrm{mg}$ of bulk sediment and boiling for one minute, respectively. Following the carbonate dissolution reaction, neutral $\mathrm{pH}$ was achieved by dilution with deionized water. As a final pre-treatment step, biogenic silica was removed. Six grams of $\mathrm{NaOH}$ pellets dissolved in $100 \mathrm{~mL}$ of deionized water were added to the sediment and the mixture was boiled for $10 \mathrm{~min}$. The solution was diluted with deionized water to neutral $\mathrm{pH}$. Prior to grain size analysis, the remaining terrigenous fraction was boiled with $300 \mathrm{mg}$ of soluble sodium pyrophosphate $\left(\mathrm{Na}_{4} \mathrm{P}_{2} \mathrm{O}_{7} \cdot 10 \mathrm{H}_{2} \mathrm{O}\right)$ to foster particle disaggregation. Grain size analysis was performed using a Coulter laser particle sizer LS200. The analysis resulted in 92 size classes varying from 0.39 to $2000 \mu \mathrm{m}$. An end-member modeling algorithm was applied to determine the proportions of distinct sediment components contributing to the measured particle size signal (Weltje, 1997; Stuut et al., 2002) (Fig. 3a-e). The algorithm output is a series of models, each containing a different number of end-members, and each model explaining a different amount of variance. The higher the number of end-members, the more variance is explained (Fig. 3d). Two key parameters are used to determine the minimum number of end-members required for a satisfactory approximation of the measured data (Prins et al., 2000; Stuut et al., 2002; Weltje, 1997). First, the coefficient of determination per size class $\left(r^{2}\right)$ is used to assess how well the model reproduces the data in each size class (Fig.3c). Second, the mean coefficient of determination $\left(r_{\text {mean }}^{2}\right)$ averaged for all size classes is used to test how well each model reproduces the average of all measured size classes (Fig. 3d). In this study, the model with a minimum number of 3 endmembers (EM1, EM2, and EM3), with $r^{2}>0.5$ and $r_{\text {mean }}^{2}$ equal to 0.79 represents the best compromise (Fig. 3).

Time series of major element intensities were generated at $1 \mathrm{~cm}$ sampling interval using the Avaatech XRF Scanner I at the University of Bremen. The core scanner was run with an excitation potential of $10 \mathrm{kV}$, a current of $250 \mu \mathrm{A}$, and $30 \mathrm{~s}$ counting time. Element intensities were normalized by dividing the total counts for each element by the sum of total
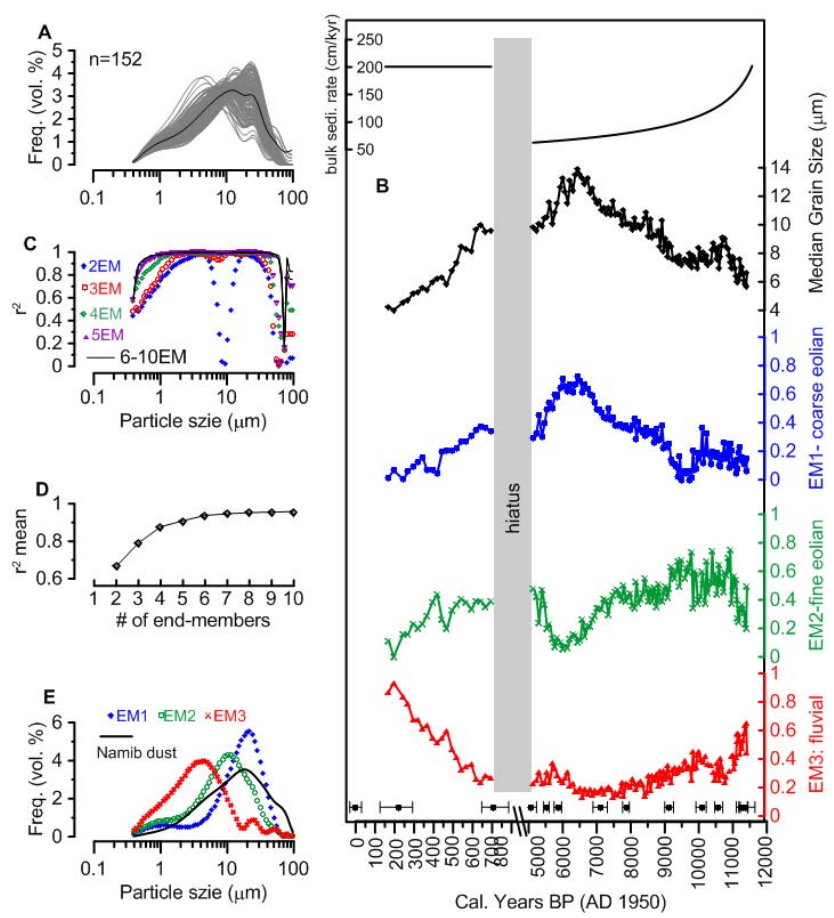

Fig. 3. Results of grain size analysis and end-member modeling for core GeoB8332-4 material. (A) Grain size distribution frequency for 152 samples (gray lines) and average grain size distribution frequency for the entire data set (black line). (B) Sedimentation rate of buld sediment, temporal distribution of median grain size and modeled end-members 1-3, indicating coarse eolian (EM1), fine eolian (EM2), and fluvial (EM3) components. Black filled circles and horizontal bars indicate age model control points and error estimate (2o) obtained from ${ }^{14} \mathrm{C}$ datings and conversion to calendar age. (C) $r^{2}$ goodness of fit of models with 2-10 end-members for each particle size class. (D) $\mathrm{r}^{2}$ mean (mean coefficient of determination) of all size classes for each end-member model. (E) Comparison of particle size distributions in EM1, EM2, and EM3 with present-day dust collected over the Walvis Ridge (Stuut et al., 2002).

counts for all measured elements. In this study we focus only on $\mathrm{Ca} / \mathrm{Al}, \mathrm{K} / \mathrm{Al}$ and $\mathrm{Ti} / \mathrm{Al}$ ratios (Fig. 4).

We analyzed $\delta^{18} \mathrm{O}$ and $\delta^{13} \mathrm{C}$ in tests of Neogloboquadrina pachyderma (sinistral) $(125-300 \mu \mathrm{m})$ from down-core samples using a Thermo MAT 253 mass spectrometer at the first author's stable isotope lab at UCSB. The mass spectrometer is coupled online to a Kiel IV Carbonate Device for automated $\mathrm{CO}_{2}$ preparation. Samples were reacted by automated individual phosphoric acid addition. Results were corrected using NBS19 standard and are reported on the Peedee Belemnite (PDB) scale. Estimates for standard error $(2 \sigma)$ in the $\delta^{18} \mathrm{O}$ and $\delta^{13} \mathrm{C}$ measurements are better than $\pm 0.07 \%$ and $\pm 0.03 \%$, respectively.

Analyses of the ${ }^{87} \mathrm{Sr} /{ }^{86} \mathrm{Sr}$ and ${ }^{143} \mathrm{Nd} /{ }^{144} \mathrm{Nd}$ ratios on the lithogenic fraction $(\leq 120 \mu \mathrm{m})$ of marine and riverine sediments were conducted on a Finnigan MAT 262 mass spectrometer using static collection mode at the Institute of 
Table 1. Details of the material used to establish an age model for GeoB8332-4. ${ }^{14} \mathrm{C}$ ages were converted to calendar ages using CALIB software (Stuiver and Reimer, 1993) (version 6.10), Marine data set 2009 (Reimer et al., 2009), and $\Delta \mathrm{R}$ of $129 \pm 19$ based on reservoir age of eastern South Atlantic water (Dewar et al., 2012; data retrieved from http://calib.qub.ac.uk/marine as of 5 May 2012). The final age models were established using polynomial (11 500-5000 yr BP) and linear (0-700 yr BP) equations.

\begin{tabular}{llrlrrrr}
\hline & & $\begin{array}{r}\text { Core } \\
\text { depth } \\
(\mathrm{cm})\end{array}$ & Material & $\begin{array}{r}14 \text { C age } \\
\text { yr BP }\end{array}$ & $\begin{array}{r}\text { Cal age yr BP } \\
\text { (median } \\
\text { probability) }\end{array}$ & $\begin{array}{r}\text { 95.4\% } \\
\text { (2 } \sigma \text { ) cal age } \\
\text { (yr BP) ranges }\end{array}$ & $\begin{array}{r}\text { Relative area } \\
\text { distribution }\end{array}$ \\
\hline KIA24630 & GeoB8332-4 & 2 & gastropods & $-220 \pm 30$ & 0 & 0 & 1 \\
KIA25048 & GeoB8332-4 & 50 & gastropods & $710 \pm 25$ & 219 & $124-291$ & 1 \\
KIA25049 & GeoB8332-4 & 145 & gastropods & $1295 \pm 30$ & 709 & $647-784$ & 1 \\
KIA25834 & GeoB8332-4 & 190 & gastropods & $4910 \pm 35$ & 5049 & $4896-5229$ & 1 \\
KIA25833 & GeoB8332-4 & 220 & gastropods & $5290 \pm 35$ & 5525 & $5438-5600$ & 1 \\
KIA25050 & GeoB8332-4 & 240 & gastropods & $5620 \pm 35$ & 5874 & $5746-5965$ & 1 \\
KIA24623 & GeoB8332-4 & 319.5 & gastropods & $6730 \pm 90$ & 7115 & $6888-7313$ & 1 \\
KIA25052 & GeoB8332-4 & 400 & gastropods & $7530 \pm 40$ & 7868 & $7759-7927$ & 1 \\
KIA25053 & GeoB8332-4 & 489 & gastropods & $8625 \pm 40$ & 9121 & $8999-9257$ & 1 \\
KIA25057 & GeoB8332-4 & 608 & gastropods & $9400 \pm 50$ & 10109 & $9917-10217$ & 1 \\
KIA25056 & GeoB8332-4 & 699 & gastropods & $9840 \pm 50$ & 10568 & $10466-10703$ & 1 \\
KIA25055 & GeoB8332-4 & 789 & gastropods & $10380 \pm 85$ & 11253 & $11102-11445$ & 0.9 \\
& & & gastropods & & & $11460-11630$ & 0.1 \\
KIA24622 & GeoB8332-4 & 789.5 & gastropods & $10440 \pm 50$ & 11290 & $11177-11428$ & 0.91 \\
KIA25059 & GeoB8332-4 & 805 & gastropods & & & $11487-11617$ & 0.09 \\
\hline
\end{tabular}

Geosciences, University of Tübingen. In order to remove the carbonate fractions of down-core samples, $500 \mathrm{mg}$ of sediment was leached with $10 \mathrm{~mL}$ acetic acid $(5 \mathrm{M})$ at room temperature for $12 \mathrm{~h}$. The detrital residues were rinsed four times with ultrapure water and centrifuged, and the supernatant was removed. A $50 \mathrm{mg}$ portion of the powdered and homogenized lithogenic fraction was spiked with a mixed ${ }^{149} \mathrm{Sm}:{ }^{150} \mathrm{Nd}$ spike prior to digestion in HF. The digested samples were dried and dissolved in $6 \mathrm{~N} \mathrm{HCl}$, dried and then redissolved in $2.5 \mathrm{~N} \mathrm{HCl}$. Analyses of NBS-SRM 987 and La Jolla Nd standards during this study yielded an average value of ${ }^{87} \mathrm{Sr} /{ }^{86} \mathrm{Sr}=0.710244 \pm 15$ and for ${ }^{143} \mathrm{Nd} /{ }^{144} \mathrm{Nd}$ $=0.511823 \pm 15$, respectively. ${ }^{87} \mathrm{Sr} /{ }^{86} \mathrm{Sr}$ ratios are normalized to ${ }^{86} \mathrm{Sr} /{ }^{88} \mathrm{Sr}=0.1194$, and the ${ }^{143} \mathrm{Nd} /{ }^{144} \mathrm{Nd} \mathrm{ra}-$ tios to ${ }^{146} \mathrm{Nd} /{ }^{144} \mathrm{Nd}=0.7219$. Results of $\mathrm{Nd}$ and $\mathrm{Sr}$ in blank measurements are 80 and $65 \mathrm{pg}$, respectively. The ${ }^{143} \mathrm{Nd} /{ }^{144} \mathrm{Nd}$ ratios are expressed as $\varepsilon \mathrm{Nd}$, where $\varepsilon \mathrm{Nd}$ is the analyzed ${ }^{143} \mathrm{Nd} /{ }^{144} \mathrm{Nd}$ ratio normalized to the "chondritic uniform reservoir" value $(0.512638$; Jacobson and Wasserburg, 1980).

\section{Results}

\subsection{Variations of terrigenous particle size}

The particle size frequency distribution shows a bi-modal distribution pattern (Fig. 3a). The time series of the median grain size is marked by a continuous increase of particle size from the early to middle Holocene and declining trends be- tween 5500 and $5000 \mathrm{yr} \mathrm{BP}$ as well as over the last $700 \mathrm{yr}$ (Fig. 3b). We used an end-member modeling technique to narrow down the number of dominant end-members to three that sufficiently explain the variability of the median grain size throughout the investigated time intervals (Fig. $3 \mathrm{~b}$ and e). End-member 3 (EM3) has a modal grain size value of $\sim 5 \mu \mathrm{m}$, and its temporal variability is characterized by a continuous decline from the early to middle Holocene (Fig. 3b). In contrast, the fraction of EM3 shows a continuous increase over the last $700 \mathrm{yr} \mathrm{BP}$, explaining up to $90 \%$ of the median grain size variability. Pronounced changes in EM2 with a modal value of $\sim 10 \mu \mathrm{m}$ are most evident between 7500 and $5500 \mathrm{yr}$ BP and between 400 and $150 \mathrm{yr} \mathrm{BP}$, and both periods are characterized by a decrease in medium grain size. The modal grain size of EM1 is $\sim 20 \mu \mathrm{m}$ and reveals a large increase between 9250 and $6500 \mathrm{yr} \mathrm{BP}$, followed by a sharp decline between 5500 and $5000 \mathrm{yr}$ BP and 700 and $150 \mathrm{yr}$ BP. Comparing the trends and magnitude of changes in the endmembers with those of the median grain size, it is evident that during the early and middle Holocene changes occurred primarily due to variations of EM1 and EM2 fractions. In contrast, during the last $700 \mathrm{yr}$, changes in EM3 dominantly shaped the marked decline in the median grain size.

The main sources and transport mechanisms that can affect temporal grain size variation over the core site are changes in riverine sediment supply, dust input, changes in sea level, and shift of depocenter. Divergent trends of sedimentation rate and changes in median grain size indicate that the variation of the latter is most likely not associated with shifts of 


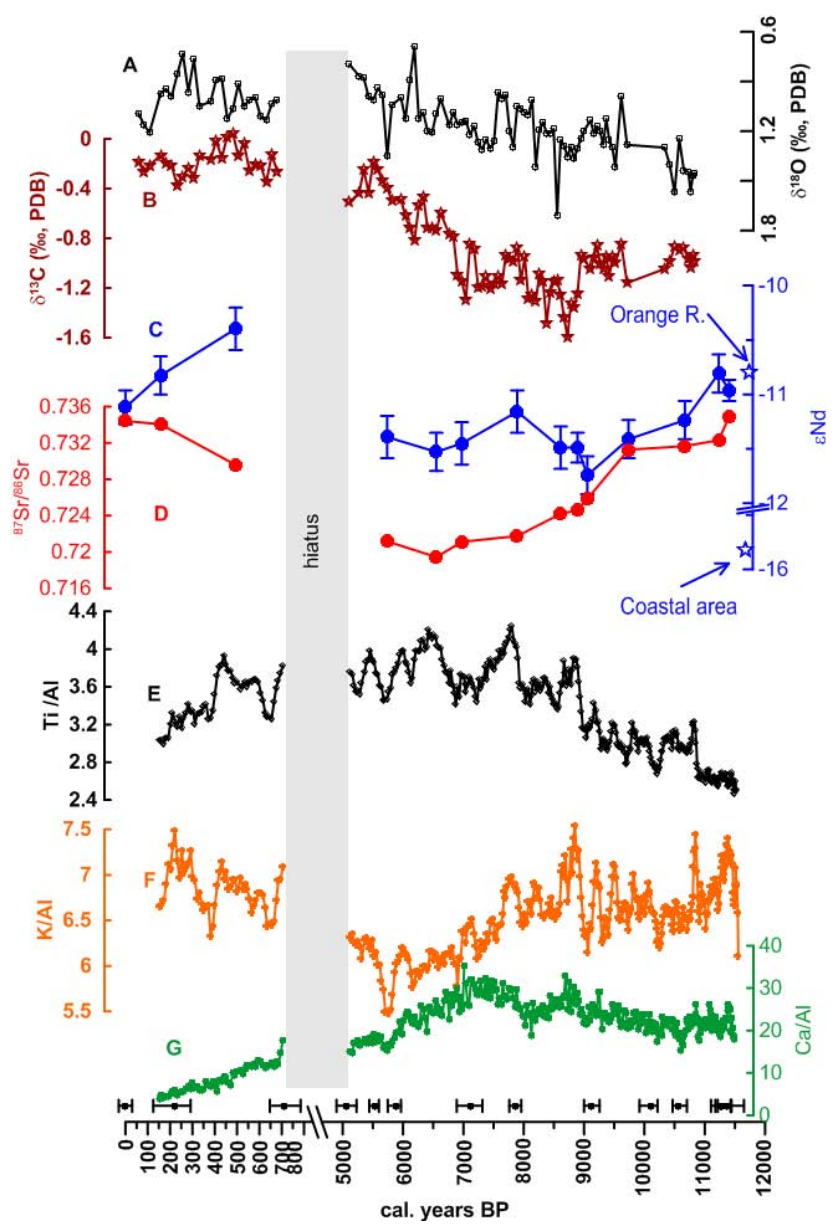

Fig. 4. Proxy time series analyzed in sediment core GeoB8332-4. (A) and (B) $\delta^{18} \mathrm{O}$ and $\delta^{13} \mathrm{C}$ analyzed in tests of $N$. pachyderma (sinistral). (C) and (D) $\varepsilon \mathrm{Nd}$ and ${ }^{87} \mathrm{Sr} /{ }^{86} \mathrm{Sr}$ analyzed in the detrital fraction. Average $\varepsilon \mathrm{Nd}$ value of the Orange River and riverbed sediments from the coastal area indicated by stars on the $y$ axis. Vertical bars indicate analytical error estimates for $\varepsilon \mathrm{Nd}$. Analytical error estimate for ${ }^{87} \mathrm{Sr} /{ }^{86} \mathrm{Sr}$ is smaller than the dots indicating individual measurements. $\mathrm{Ti} / \mathrm{Al}(\mathbf{E}), \mathrm{K} / \mathrm{Al}(\mathbf{F})$, and $\mathrm{Ca} / \mathrm{Al}(\mathbf{G})$ analyzed in bulk sediment of GeoB8332-4 using XRF-Scanning. Black filled circles and horizontal bars indicate age model control points and error estimate $(2 \sigma)$ related to ${ }^{14} \mathrm{C}$ measurements and conversion to calendar age, respectively.

a depocenter (Fig. 3). Furthermore, with the exception of the early Holocene, regional sea level changes (Compton, 2001) and sedimentation rate seem unrelated, with sea level rise and EM1 increase during middle Holocene (8-6.5 kyr BP) and increase in EM3 and sea level rise during the last 700 cal years BP (Compton, 2001). Grain size analysis of suspended particles collected from the main tributaries of the Orange River shows $\sim 10 \%$ clay $(<2 \mu \mathrm{m}), \sim 70 \%$ fine silt $(2-38 \mu \mathrm{m}), \sim 15 \%$ coarse silt $(38-63 \mu \mathrm{m})$, and $\sim 5 \%$ sand $(>63 \mu \mathrm{m})$ (Compton and Maake, 2007). The sand and coarse silt fractions in the suspended matter of the Orange River

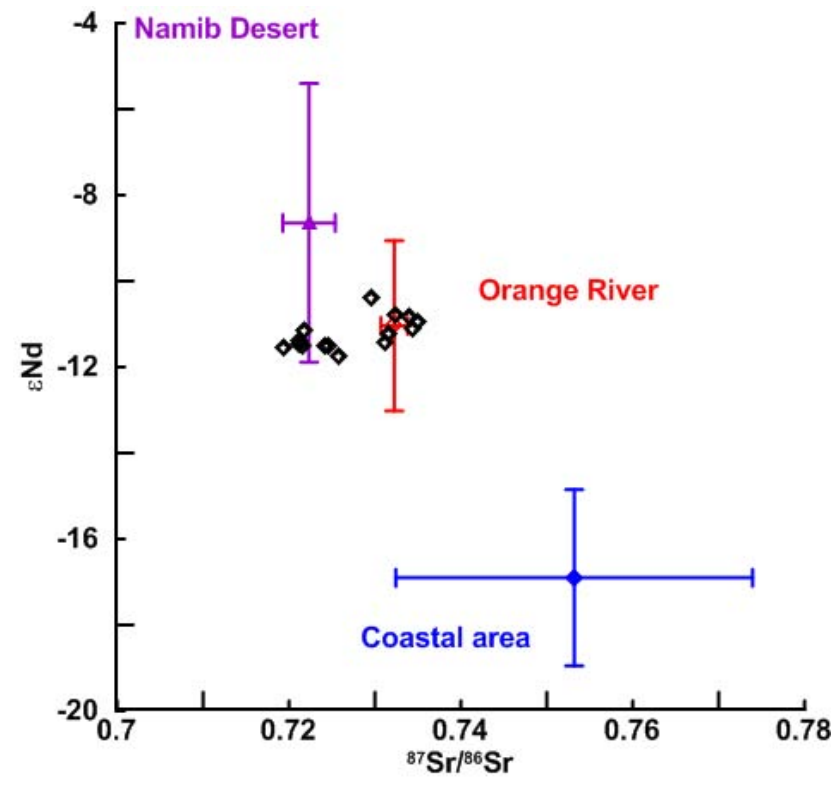

Fig. 5. Sr and $\mathrm{Nd}$ isotope signatures of the main sediment sources and temporal variation in sediment core GeoB8332-4 (open diamonds). Mean ${ }^{87} \mathrm{Sr} /{ }^{86} \mathrm{Sr}$ and eNd values and standard deviations of Namib Desert dust $\left({ }^{87} \mathrm{Sr} /{ }^{86} \mathrm{Sr}=0.722 \pm 0.003\right.$ and $\varepsilon \mathrm{Nd}=-8.65 \pm 3.24, n=6$ ) (Grousset et al., 1992), sediment of coastal area $\left({ }^{87} \mathrm{Sr} /{ }^{86} \mathrm{Sr}=0.75318 \pm 0.02\right.$ and $\varepsilon \mathrm{Nd}=-16.9 \pm 2.05$, $n=2$ ), Orange River sediments collected at Alexander Bay and Vioolsdrift (see Fig. 1) and main catchment of Orange River (Dia et al., 1990) ${ }^{87} \mathrm{Sr} /{ }^{86} \mathrm{Sr}=0.7322 \pm 0.0015, n=4$ and $\varepsilon \mathrm{Nd}=-11.04 \pm 1.98, n=6)$.

are quickly trapped in the delta and prodelta, and carried away to the northwest by wave-driven littoral drift (Mabote, 1997; Rogers and Rau, 2006). While the northeasterly bottom water current is too weak to carry sand and coarse silt fractions, it transports the fine silt and clay components of the Orange sediment load to the southeastern segment of the mudbelt (Mabote, 1997; Rogers and Rau, 2006). Our core site is located $57 \mathrm{~km}$ away from the delta of the Orange River (Fig. 1), and the median grain size of the core top samples (100-200 cal years BP) shows value of $4 \mu \mathrm{m}$, a sedimentation rate of $2 \mathrm{~mm}$ per year, and EM3 and EM2 explaining more than $97 \%$ of the grain size variation. This observation shows that only the fine fraction $(\leq 10 \mu \mathrm{m})$ of Orange River sediment arrives at our core site. Based on the dominance of the fine fraction, we hypothesize that EM3 presents a fluvial component, an assumption that is supported by the element ratios and isotope signatures shown below.

Dust input from the Namib Desert and Namaqualand presents an important sediment source for the eastern South Atlantic and the mudbelt (Mabote, 1997; Shannon and Anderson, 1982; Stuut et al., 2002; Mahowald et al., 2005). A model-based study estimates that dust deposition off the Holgat River accounts for $7-10 \mathrm{~g} \mathrm{~m}^{-2} \mathrm{yr}^{-1}$ (Mahowald et al., 2005) for which no grain size analysis is available. Analysis 
Table 2. Results of $\mathrm{Sr}$ and $\mathrm{Nd}$ isotope analysis in river and marine core sediments.

\begin{tabular}{|c|c|c|c|c|c|c|c|}
\hline \multicolumn{8}{|c|}{ River samples } \\
\hline Location & Location & Sediment depth $(\mathrm{cm})$ & Material & Size fraction & ${ }^{87} \mathrm{Sr} /{ }^{86} \mathrm{Sr}, \pm 2 \sigma$ & ${ }^{143} \mathrm{Nd} /{ }^{144} \mathrm{Nd}, \pm 2 \sigma$ & $\mathrm{eNd}, \pm 2 \sigma$ \\
\hline Buffels River & $29^{\circ} 41.97^{\prime} \mathrm{S} / 17^{\circ} 42.75^{\prime} \mathrm{E}$ & surface $(0-1 \mathrm{~cm})$ & riverine bed sediment & $<125 \mu \mathrm{m}$ & $0.76760 \pm 10^{-5}$ & $0.51170 \pm 10^{-5}$ & $-18.20 \pm 0.12$ \\
\hline Buffels River & $29^{\circ} 36.79^{\prime} \mathrm{S} / 17^{\circ} 31.45^{\prime} \mathrm{E}$ & surface $(0-1 \mathrm{~cm})$ & riverine bed sediment & $<125 \mu \mathrm{m}$ & $0.75528 \pm 10^{-5}$ & $0.51176 \pm 10^{-5}$ & $-17.05 \pm 0.12$ \\
\hline Dry riverbed & $28^{\circ} 47.94^{\prime} \mathrm{S} / 17^{\circ} 39.06^{\prime} \mathrm{E}$ & surface $(0-1 \mathrm{~cm})$ & riverine bed sediment & $<125 \mu \mathrm{m}$ & $0.76666 \pm 10^{-5}$ & $0.51169 \pm 10^{-5}$ & $-18.41 \pm 0.12$ \\
\hline Olifants River & $31^{\circ} 40.76^{\prime} \mathrm{S} / 18^{\circ} 11.98^{\prime} \mathrm{E}$ & surface $(0-1 \mathrm{~cm})$ & riverine bed sediment & $<125 \mu \mathrm{m}$ & $0.72423 \pm 10^{-5}$ & $0.51207 \pm 10^{-5}$ & $-11.12 \pm 0.12$ \\
\hline Holgat River & $28^{\circ} 55.86^{\prime} \mathrm{S} / 16^{\circ} 46.44^{\prime} \mathrm{E}$ & surface $(0-1 \mathrm{~cm})$ & riverine bed sediment & $<125 \mu \mathrm{m}$ & $0.72320 \pm 10^{-5}$ & $0.51192 \pm 10^{-5}$ & $-13.97 \pm 0.12$ \\
\hline Orange River & $28^{\circ} 36^{\prime} 07^{\prime \prime} \mathrm{S} / 16^{\circ} 28.16^{\prime} \mathrm{E}$ & surface $(0-1 \mathrm{~cm})$ & riverine bed sediment & $>2 \mu \mathrm{m}$ & $0.735538 \pm 10^{-6}$ & $0.512032 \pm 7 \times 10^{-6}$ & $-11.78 \pm 0.14$ \\
\hline Orange River & $28^{\circ} 46^{\prime} 41^{\prime \prime} \mathrm{S} / 17^{\circ} 38^{\prime} 63^{\prime \prime} \mathrm{E}$ & surface $(0-1 \mathrm{~cm})$ & riverine susp. sediment & $<20 \mu \mathrm{m}$ & $0.733628 \pm 10^{-6}$ & $0.512015 \pm 7 \times 10^{-6}$ & $-12.11 \pm 0.14$ \\
\hline Orange River & $28^{\circ} 36^{\prime} 07^{\prime \prime} \mathrm{S} / 16^{\circ} 28^{\prime} 16^{\prime \prime} \mathrm{E}$ & surface $(0-1 \mathrm{~cm})$ & riverine susp. sediment & $>2 \mu \mathrm{m}$ & $0.732447 \pm 10^{-6}$ & $0.511991 \pm 9 \times 10^{-6}$ & $-12.58 \pm 0.18$ \\
\hline Orange River & $28^{\circ} 46^{\prime} 41^{\prime \prime} \mathrm{S} / 17^{\circ} 38.63^{\prime} \mathrm{E}$ & surface $(0-1 \mathrm{~cm})$ & riverine bed sediment & $<120 \mu \mathrm{m}$ & $0.727351 \pm 27 \times 10^{-6}$ & $0.511956 \pm 8 \times 10^{-6}$ & $-13.26 \pm 0.16$ \\
\hline \multicolumn{8}{|c|}{ GeoB8332-4 samples } \\
\hline Core & Sediment depth $(\mathrm{cm})$ & cal. age (yr, BP) & Material & Size fraction & ${ }^{87} \mathrm{Sr} /{ }^{86} \mathrm{Sr}, \pm 2 \sigma$ & ${ }^{143} \mathrm{Nd} /{ }^{144} \mathrm{Nd}, \pm 2 \sigma$ & $\mathrm{eNd}, \pm 2 \sigma$ \\
\hline GeoB8332-4 & 2 & 0 & Terrigenous fraction & $<125 \mu \mathrm{m}$ & $0.734426 \pm 10^{-6}$ & $0.512066 \pm 8 \times 10^{-6}$ & $-11.12 \pm 0.16$ \\
\hline GeoB8332-4 & 35 & 157.2 & Terrigenous fraction & $<125 \mu \mathrm{m}$ & $0.734077 \pm 10^{-6}$ & $0.512081 \pm 9 \times 10^{-6}$ & $-10.83 \pm 0.18$ \\
\hline GeoB8332-4 & 102.5 & 493.6 & Terrigenous fraction & $<125 \mu \mathrm{m}$ & $0.729606 \pm 10^{-6}$ & $0.512103 \pm 10^{-5}$ & $-10.40 \pm 0.20$ \\
\hline GeoB8332-4 & 180 & 879.8 & Terrigenous fraction & $<125 \mu \mathrm{m}$ & $0.721613 \pm 10^{-6}$ & $0.512047 \pm 7 \times 10^{-6}$ & $-11.49 \pm 0.14$ \\
\hline GeoB8332-4 & 230 & 5736.7 & Terrigenous fraction & $<125 \mu \mathrm{m}$ & $0.721173 \pm 10^{-6}$ & $0.512052 \pm 10^{-5}$ & $-11.39 \pm 0.20$ \\
\hline GeoB8332-4 & 285 & 6551.2 & Terrigenous fraction & $<125 \mu \mathrm{m}$ & $0.719441 \pm 10^{-6}$ & $0.512045 \pm 9 \times 10^{-6}$ & $-11.53 \pm 0.18$ \\
\hline GeoB8332-4 & 315 & 6972.6 & Terrigenous fraction & $<125 \mu \mathrm{m}$ & $0.721116 \pm 9 \times 10^{-7}$ & $0.512049 \pm 10^{-5}$ & $-11.45 \pm 0.20$ \\
\hline GeoB8332-4 & 385 & 7892.7 & Terrigenous fraction & $<125 \mu \mathrm{m}$ & $0.72176 \pm 10^{-5}$ & $0.512064 \pm 10^{-5}$ & $-11.16 \pm 0.20$ \\
\hline GeoB8332-4 & 445 & 8611.2 & Terrigenous fraction & $<125 \mu \mathrm{m}$ & $0.724198 \pm 7 \times 10^{-6}$ & $0.512047 \pm 10^{-5}$ & $-11.49 \pm 0.20$ \\
\hline GeoB8332-4 & 470 & 8891.5 & Terrigenous fraction & $<125 \mu \mathrm{m}$ & $0.724615 \pm 9 \times 10^{-6}$ & $0.512047 \pm 7 \times 10^{-6}$ & $-11.49 \pm 0.20$ \\
\hline GeoB8332-4 & 485 & 9054.2 & Terrigenous fraction & $<125 \mu \mathrm{m}$ & $0.725862 \pm 10^{-5}$ & $0.512034 \pm 9 \times 10^{-6}$ & $-11.74 \pm 0.18$ \\
\hline GeoB8332-4 & 552.5 & 9736.5 & Terrigenous fraction & $<125 \mu \mathrm{m}$ & $0.731262 \pm 8 \times 10^{-7}$ & $0.512051 \pm 9 \times 10^{-6}$ & $-11.41 \pm 0.18$ \\
\hline GeoB8332-4 & 662.5 & 10672.6 & Terrigenous fraction & $<125 \mu \mathrm{m}$ & $0.731666 \pm 9 \times 10^{-6}$ & $0.51206 \pm 9 \times 10^{-6}$ & $-11.24 \pm 0.18$ \\
\hline GeoB8332-4 & 745 & 11231.7 & Terrigenous fraction & $<125 \mu \mathrm{m}$ & $0.732319 \pm 10^{-5}$ & $0.512082 \pm 9 \times 10^{-6}$ & $-10.81 \pm 0.18$ \\
\hline GeoB8332-4 & 775 & 11404.7 & Terrigenous fraction & $<125 \mu \mathrm{m}$ & $0.73493 \pm 8 \times 10^{-6}$ & $0.512074 \pm 5 \times 10^{-6}$ & $-10.96 \pm 0.10$ \\
\hline
\end{tabular}

of grain size of dust collected above the Walvis Ridge (Stuut et al., 2002) shows a broad uni-modal distribution with a modal value of $20 \mu \mathrm{m}$ that is very similar to that of EM1 (Fig. 3e). Due to the proximity of the dust source to our core site, it is most likely that an enhanced dust deposition leads to an increase of grain size. In our time series, EM1 presents the end-member with the largest model grain size of $20 \mu \mathrm{m}$. EM1 and and EM2 increased significantly during the mid-Holocene. Based on the proximity of the dust sources to our core site and the weak bottom water current, we hypothesize that EM1 reflects sediment largely related to dust input. Following the approach described by Stuut et al. (2002, 2004), we calculated indices for relative humidity (EM3/EM1 + EM2 + EM3) and wind strength changes $($ EM1/EM1 + EM2) throughout the investigated time interval (see discussion section).

Exploring whether a strengthening of northeasterly bottom water current or an increase of sediment input from local rivers could have contributed to the mid-Holocene increase of grain size, it requires additional insights from the radiogenic and element record that is described below.

\subsection{Variation of selected major elements}

Figure 4 shows down-core variation of $\mathrm{Ca} / \mathrm{Al}, \mathrm{K} / \mathrm{Al}$, and $\mathrm{Ti} / \mathrm{Al}$ intensity ratios. $\mathrm{Ca} / \mathrm{Al}$ primarily reflects changes in biogenic carbonate and shows that carbonate productivity was relatively high between 11500 and 6750 cal years BP, followed by a continuous decline. We focus on $\mathrm{K} / \mathrm{Al}$ and $\mathrm{Ti} / \mathrm{Al}$ to address changes in terrigenous input and to infer possible weathering and transport mechanisms. On the millennial scale, $\mathrm{K} / \mathrm{Al}$ ratios show a continuous decline starting from 11500 to $6000 \mathrm{cal}$ years BP. An increasing K/Al trend is evident between 5500 and 5000 cal years BP and during the last 700 cal years BP. A millennial-scale trend in $\mathrm{Ti} / \mathrm{Al}$ reveals increasing values from the early to middle Holocene and declining values from 6500 to $5000 \mathrm{yr}$ BP as well as from 700 to $100 \mathrm{yr}$ BP. Overall, millennial-scale trends in $\mathrm{K} / \mathrm{Al}$ and $\mathrm{Ti} / \mathrm{Al}$ ratios evolve in divergent directions, indicating different sources, weathering, or transport mechanisms. Clay mineralogical and chemical analyses of soil and suspended sediments in the catchment of the Orange River reveal that erosion products of the Karoo Supergroup series (Palaeozoic to Mesozoic deposits) are rich in illite, K-feldspar, and smectite and show high $\mathrm{K}$ concentration (Compton and Maake, 2007). Furthermore, erosion products of the Karoo Supergroup series present the dominant fraction in the suspended sediment of the Orange River (Compton and Maake, 2007). Within the mudbelt between the Orange and the Olifants rivers, concentration of $\mathrm{K}$ shows an increasing trend with low $\mathrm{K}$ values in the north (relatively proximal to the Orange River) as compared to those in the south (Govin et al., 2012). This distribution pattern arises due to grain size sorting by bottom currents, with coarse sediments in the north and predominantly clayey sediments in the south (Rogers and Rau, 2006). We suggest that temporal 
Table 3. Summary of geochemical parameters presented in this study and paleo-environmental interpretation.

\begin{tabular}{|c|c|c|}
\hline Parameters & Proxy for: & Multi-proxy-based inference of environmental conditions \\
\hline $\begin{array}{l}{ }^{87} \mathrm{Sr} /{ }^{86} \mathrm{Sr} \text { in } \\
\text { detrital sediment }\end{array}$ & $\begin{array}{l}\text { Changes in sediment source, } \\
\text { changes in grain size }\end{array}$ & $\begin{array}{l}\text { Increase of }{ }^{87} \mathrm{Sr} /{ }^{86} \mathrm{Sr} \text { ratio concomitant with relatively negative } \\
\text { eNd values and decrease of grain size suggest humid conditions } \\
\text { in the coastal area }\end{array}$ \\
\hline $\begin{array}{l}{ }^{143} \mathrm{Nd} /{ }^{144} \mathrm{Nd} \\
(\mathrm{eNd}) \text { in detrital } \\
\text { sediment }\end{array}$ & Changes in sediment source & $\begin{array}{l}\text { Relatively negative eNd values and increase of fine sediments } \\
\text { (EM3) indicate relatively humid conditions in the coastal area }\end{array}$ \\
\hline $\begin{array}{l}\delta^{18} \mathrm{O} \\
(N . \text { pachyderma })\end{array}$ & $\begin{array}{l}\text { Changes in calcification tempera- } \\
\text { ture, changes in } \delta^{18} \mathrm{O} \text { of seawater }\end{array}$ & $\begin{array}{l}\text { Relatively negative } \delta^{18} \mathrm{O} \text {-ivc: relatively cold temperature due to } \\
\text { strengthened upwellings and weak (enhanced) Agulhas leakage }\end{array}$ \\
\hline $\begin{array}{l}\delta^{13} \mathrm{C} \\
(N . \text { pachyderma })\end{array}$ & $\begin{array}{l}\text { Changes in upwelling intensity, } \\
\text { changes in the amount and C- } \\
\text { isotope signatures of riverine or- } \\
\text { ganic matter }\end{array}$ & $\begin{array}{l}\text { Relatively negative (positive) } \delta^{13} \mathrm{C} \text { values due to strengthened } \\
\text { (weak) upwellings and weak (enhanced) Agulhas leakage in } \\
\text { response to northerly (southerly) position of austral westerlies }\end{array}$ \\
\hline $\begin{array}{l}\text { Graize end- } \\
\text { members }\end{array}$ & $\begin{array}{l}\text { EM1: eolian input, EM3: } \\
\text { change in fluvial input }\end{array}$ & $\begin{array}{l}\text { Decrease in EM1 and increase in EM3 in conjunction with } \\
\text { relatively negative eNd values: humid condition in the coastal } \\
\text { area }\end{array}$ \\
\hline $\mathrm{Ti} / \mathrm{Al}$ & $\begin{array}{l}\text { Eolian input, changes in sediment } \\
\text { source }\end{array}$ & $\begin{array}{l}\text { Increase in } \mathrm{Ti} / \mathrm{Al} \text { in conjunction with relatively positive eNd } \\
\text { values: dry conditions in the coastal area }\end{array}$ \\
\hline $\mathrm{K} / \mathrm{Al}$ & $\begin{array}{l}\text { Fluvial input, changes in } \\
\text { sediment source }\end{array}$ & $\begin{array}{l}\text { Increase in } \mathrm{K} / \mathrm{Al} \text { in conjucntion with relatively negative eNd } \\
\text { values: humid conditions in the coastal area }\end{array}$ \\
\hline
\end{tabular}

$\mathrm{K} / \mathrm{Al}$ variation within our site indicates changes in K-rich fine sediments and the amount of fluvial input. A comprehensive analysis of major elements in Atlantic surface sediments, as well as a compilation dust and riverine suspended sediment data, indicate that with few exceptions high $\mathrm{Ti} / \mathrm{Al}$ is related to enhanced dust inputs, whereas riverine suspended and surface sediments off large river systems show low Ti / Al (Govin et al., 2012). Consistent with the Atlanticwide pattern, Ti analysis in surface sediments of the mudbelt show a lower $\mathrm{Ti}$ concentration in sites relatively proximal to the Orange River outflow as compared to Ti value obtained in surface sediment of the southern mudbelt (Govin et al., 2012). The distribution pattern of Ti within the mudbelt between the Orange and Olifants rivers (Govin et al., 2012) corresponds with the abundance of ilmenite, a Ti-bearing heavy mineral, whose abundance increases in the central and southern mudbelt (Rogers and Rau, 2006), indicating the ilmenite predominantly stems from local sources. Therefore, we argue that relatively high $\mathrm{Ti} / \mathrm{Al}$ values and concomitant increase of grain size during the mid-Holocene indicates increased sediment input due to enhanced dust mobilization in Namaquland. In contrast, high $\mathrm{K} / \mathrm{Al}$ paralleled by decrease in grain size indicates increased fluvial inputs from local and Orange rivers. Emphasizing that the Orange River is the most dominant sediment source for the mudbelt, changes in fluvial sediment supply from the coastal areas can be identified by its radiogenic isotope signatures.

\subsection{Radiogenic isotope signature of the terrigenous sediments}

$\mathrm{Sr}$ and $\mathrm{Nd}$ isotope signatures of terrigenous components in marine sediments provide a useful tool to assess sediment sources and transport mechanisms (Bayon et al., 2003; Grousset and Biscaye, 2005; Weldeab et al., 2002a, b, 2011; Meyer et al., 2011). We established a low-resolution time series of $\mathrm{Sr}$ and $\mathrm{Nd}$ isotopes in core GeoB8332-4. We also conducted $\mathrm{Nd}$ and $\mathrm{Sr}$ isotope analysis of suspended and riverbed sediments from the Orange River and ephemeral rivers in the coastal area (Figs. 1, 4c-d, and 5). Suspended and riverbed sediments of the Orange River that were collected at Alexander Bay and Vioolsdrift (Fig. 1) show average values of ${ }^{87} \mathrm{Sr} /{ }^{86} \mathrm{Sr}=0.73224 \pm 0.0016(n=4)$ and $\varepsilon \mathrm{Nd}=-11.04 \pm 1.98(n=4)$. We note that dissolved Sr isotope values in water from the Caledon River (a tributary of the Orange River) and the Upper Orange River are much lower, showing average ${ }^{87} \mathrm{Sr} /{ }^{86} \mathrm{Sr}$ values of 0.708 and 0.713 , respectively (de Villiers et al., 2000). In contrast, the isotope signatures of dissolved $\mathrm{Sr}$ in the water of the Vaal River (a major tributary of the Orange River) show, on average, a ${ }^{87} \mathrm{Sr} /{ }^{86} \mathrm{Sr}$ ratio of 0.731 (de Villiers et al., 2000). This observation shows that more work is needed to decipher which minerals present the main source for dissolved $\mathrm{Sr}$ and which isotope values characterize suspended sediment loads in the main tributaries of the Orange River. Nonetheless, we argue that ${ }^{87} \mathrm{Sr} /{ }^{86} \mathrm{Sr}$ signatures of $\sim 0.73$ 
for suspended sediments in the Lower Orange River together with an $\varepsilon \mathrm{Nd}$ signature of $=-9.19 \pm 1.45(n=3)$ from Beaufort Group shales which form the upper portion of the Karoo Supergroup (Dia et al., 1990) may represent integrated isotope signatures for suspended sediments of the Orange River (Fig. 5). Average values of $0.75318 \pm 0.02(n=4)$ and $-16.9 \pm 2.05(n=4)$ for ${ }^{87} \mathrm{Sr} /{ }^{86} \mathrm{Sr}$ and $\varepsilon \mathrm{Nd}$ signatures characterize riverbed sediments from the local rivers (Figs. 1 and 5, Table 2). We exclude the ${ }^{87} \mathrm{Sr} /{ }^{86} \mathrm{Sr}$ and $\varepsilon \mathrm{Nd}$ values of Olifants River (Fig. 1 and Table 2) because we suspect that the sampling site is influenced by tide-mobilized sediments from the shallow water. A third sediment source is dust input from the Namib Desert. Analysis of Namib Desert dust samples (Grousset et al., 1992) shows average ${ }^{87} \mathrm{Sr} /{ }^{86} \mathrm{Sr}$ and $\varepsilon \mathrm{Nd}$ values of $0.72232 \pm 0.003(n=8)$ and $-8.64 \pm 3.24$, $(n=8)$, respectively

${ }^{87} \mathrm{Sr} /{ }^{86} \mathrm{Sr}$ and $\varepsilon \mathrm{Nd}$ values in the time series of the sediment core vary between 0.73493 and 0.719441 and -10.39 and -11.74 , respectively. The down-core variation of $\mathrm{Nd}$ isotope values is relatively small due to the dominance of Orange River sediments (Figs. 4 and 5). It is also important to note that changes in grain size have an effect on the ${ }^{87} \mathrm{Sr} /{ }^{86} \mathrm{Sr}$ signature (Eisenhauer et al., 1999; Meyer et al., 2011). Because the down-core record reveals significant grain size variation (Fig. 3n), the time series of ${ }^{87} \mathrm{Sr} /{ }^{86} \mathrm{Sr}$ likely harbors an imprint of grain size changes. Therefore we emphasize that the assessment of changes in source or transport mechanism is best achieved by combining the results of all proxy parameters. Consistent with the time series of median grain size and $\mathrm{K} / \mathrm{Al}$ (Figs. $3 \mathrm{~b}$ and $4 \mathrm{f}$ ), the radiogenic isotope signatures show a trend that is marked by decreasing ${ }^{87} \mathrm{Sr} /{ }^{86} \mathrm{Sr}$ ratios and $\varepsilon \mathrm{Nd}$ values during the early Holocene (11600 to 9000 cal years BP). During the middle Holocene, ${ }^{87} \mathrm{Sr} /{ }^{86} \mathrm{Sr}$ ratios continue to decrease until 6000 cal years $\mathrm{BP}$, while $\varepsilon \mathrm{Nd}$ remains at a constant level similar to the end of the early Holocene (9000 cal years BP). In contrast, the youngest time interval (700-0 BP) reveals increasing ${ }^{87} \mathrm{Sr} /{ }^{86} \mathrm{Sr}$ ratios and decreasing $\varepsilon \mathrm{Nd}$ values parallel to an increase in fluvial sediment supply, as suggested by the decrease in median grain size, increase of EM3 and $\mathrm{K} / \mathrm{Al}$ ratio (Fig. 3).

On the basis of the temporal patterns depicted in Figs. 4c$\mathrm{d}$ and 5, the following relationship emerges between downcore variability of $\mathrm{Sr}$ and $\mathrm{Nd}$ isotopes and possible shifts in main sediment sources: from the early to middle Holocene, ${ }^{87} \mathrm{Sr} /{ }^{86} \mathrm{Sr}$ and $\varepsilon \mathrm{Nd}$ values decline from $0.7336 \pm 0.0018$ $(n=2)$ to $0.7242 \pm 0.0042(n=9)$ and from $-10.88 \pm 0.11$ $(n=2)$ to $-11.44 \pm 0.16(n=9)$, respectively. Concomitant increase in median grain size in the terrigenous sediments may have contributed to the relatively large decline in the ${ }^{87} \mathrm{Sr} /{ }^{86} \mathrm{Sr}$ ratio. High $\mathrm{Ti} / \mathrm{Al}$ values and the dominance of EM1 with a modal grain size of $\sim 20 \mu \mathrm{m}$ correspond with the changes in the $\mathrm{Sr}$ and $\mathrm{Nd}$ isotopes. This suggests an enhanced influence of eolian input or coarse fluvial sediment input from the Holgat River during the middle Holocene. However, the relatively low sedimentation rate and low $\mathrm{K} / \mathrm{Al}$ ratio argue against increased fluvial influence. From $700 \mathrm{cal}$ years BP toward the core top, ${ }^{87} \mathrm{Sr} /{ }^{86} \mathrm{Sr}$ and $\varepsilon \mathrm{Nd}$ reveal increasing and declining values, respectively. This trend is accompanied by changes in median grain size from coarse to fine silt and clay, an increase in $\mathrm{K} / \mathrm{Al}$, and a decrease in $\mathrm{Ti} / \mathrm{Al}$. Changes in all parameters thus indicate increase of river sediment supply over the last $700 \mathrm{yr}$. More importantly, the negative trend in $\varepsilon \mathrm{Nd}$ and an increase in ${ }^{87} \mathrm{Sr} /{ }^{86} \mathrm{Sr}$ suggest a relative increase of sediment input from the local rivers.

\section{4 $\delta^{18} \mathrm{O}$ and $\delta^{13} \mathrm{C}$ in tests of Neogloboquadrina pachyderma (sinistral)}

The results of $\delta^{18} \mathrm{O}$ and $\delta^{13} \mathrm{C}$ analysis in tests of Neogloboquadrina pachyderma (sinistral) are shown in Fig. $4 \mathrm{a}$ and $\mathrm{b}$. The long-term carbon isotope trend is marked by an increase of $\delta^{13} \mathrm{C}$ from an average value of $-1.1 \pm 0.17(n=55)$ between 10800 and $7000 \mathrm{yr}$ BP to $-0.54 \pm 0.19(n=21)$ between 6800 and $5100 \mathrm{yr}$ BP. On average, a decreasing trend in $\delta^{13} \mathrm{C}$ is evident in the youngest section of the record (100700 cal years BP), showing a mean value of $-0.18 \pm 0.1$ $(n=26)$.

Changes in the isotope signature of dissolved inorganic carbon (DIC) and its manifestation in the carbon isotope composition of planktonic foraminiferal tests can be influenced by several processes. Due to the hydrographic, bathymetric, and depositional setting of our core site, a relatively low organic matter burial efficiency coupled with suspension and vertical mixing by bottom currents and internal waves (Compton et al., 2009), and ensuing demineralization of organic matter, may present a source of DIC variability. Estimates of particulate and dissolved organic matter from the Orange River entering the delta system, on average, account for $62000 \mathrm{tyr}^{-1}$, and approximately half of this amount is buried in the subaqueous delta plains (Compton et al., 2009). $\delta^{13} \mathrm{C}$ values of organic matter in soil and suspended matter in the catchment and tributaries of the Orange River cover a wide range, varying between $-12.7 \%$ and $-21.5 \%$ (Compton and Maake, 2007). In contrast, measurements of $\delta^{13} \mathrm{C}$ in organic matter along the mudbelt show rapidly decreasing $\delta^{13} \mathrm{C}$ values away from riverine influenced zone, suggesting that most of the riverine organic matter is composed of $\mathrm{C}_{4}$ plant remains and that it is deposited predominantly in the delta and prodelta systems (Meadows et al., 2002). Changes in the river input of $\mathrm{C}_{3}$ and $\mathrm{C}_{4}$ plant organic matter remain difficult to assess. Approximately $42 \mathrm{~km}$ southeast of the Orange River mouth, the average value of $\delta^{13} \mathrm{C}$ in organic matter is $\sim-19.8 \%$, which is close to the average value of marine organic matter (varying between $-20 \%$ and $-21 \%$ o) (Meadows et al., 2002). Our core site is approximately $57 \mathrm{~km}$ southeast of the Orange River delta. Therefore, while carbon isotopic imprint of riverine organic matter due to shift in $C_{3}$ and $C_{4}$ plant may changes throughout the investigated time interval, the influence of riverine DIC over our site is 
low, and wind-induced upwelling of demineralized marine organic carbon provides the dominant source of DIC. Hence, the long-term variability of $\delta^{13} \mathrm{C}$ in our record may indicate changes in the strength of coastal water upwelling, with relatively low $\delta^{13} \mathrm{C}$ values indicating strong upwelling.

The $\delta^{18} \mathrm{O}$ record reflects a composite imprint of changes in continental ice volume, calcification temperature, and fresh water input. We removed the ice volume component from the foraminiferal $\delta^{18} \mathrm{O}$ record using the eustatic level record from Bard et al. (1996). A prominent feature in the icevolume-corrected $\delta^{18} \mathrm{O}\left(\delta^{18} \mathrm{O}_{\mathrm{ivc}}\right)$ record throughout the early and middle Holocene is a gradually declining trend that is interrupted by precipitous rises in $\delta^{18} \mathrm{O}_{\mathrm{ivc}}$. On the multicentennial to millennial scale, the $\delta^{18} \mathrm{O}_{\mathrm{ivc}}$ record reveals variation of $0.5 \%$ from the early to the middle Holocene (Fig. 5). After 7500 cal years BP a gradual decline in $\delta^{18} \mathrm{O}_{\text {ivc }}$ continues until $5000 \mathrm{BP}$, culminating in the lowest $\delta^{18} \mathrm{O}_{\mathrm{ivc}}$ values. Submillennial-scale change is apparent between 7500 and 5000 cal years BP but not as prominently as in the earliest Holocene. Under modern climate conditions, Orange River runoff of $\sim 11 \mathrm{~km}^{3} \mathrm{yr}^{-1}$ is rapidly mixed with upwelled surface waters and leaves only a negligible salinity imprint in the coastal oceanic waters. Therefore, it is likely that during the middle Holocene the decline in the $\delta^{18} \mathrm{O}_{\text {ivc }}$ record predominantly reflects increase in the foraminiferal calcification temperature with $0.21 \% 0^{\circ} \mathrm{C}^{-1}$ (Bemis et al., 1998). Parallel changes in the $\delta^{18} \mathrm{O}$ and $\delta^{13} \mathrm{C}$ time series during the early and middle Holocene with decreasing $\delta^{18} \mathrm{O}$ and increasing $\delta^{13} \mathrm{C}$ values most likely indicate millennial-scale episodes of weakened upwelling and resultant surface water warmth by approximately $2{ }^{\circ} \mathrm{C}$ (Fig. $6 \mathrm{c}$ and d).

\section{Discussion}

\subsection{Early and middle Holocene climate variability}

We identify three periods of millennial-scale climate changes during the early and middle Holocene. During the early Holocene (11500-11000 cal years BP) relatively positive $\varepsilon \mathrm{Nd}$ values and a high fraction of fine sediment indicate a dominant contribution of the Orange River to the enhanced fluvial input (Figs. 4c and 6f). Between 11000 and $9500 \mathrm{cal}$ years BP, $\varepsilon \mathrm{Nd}$ values shifted slightly toward the value of the coastal area (Fig. 4c) and the fraction of fine sediment remained, probably indicating wet climate in the coastal area. Around 9200 cal years BP, we note the onset of a continuous increase of grain size reaching its maximum between 6000 and 5500 cal years BP (Fig. 6f), a decrease in sedimentation rate, and a decline in $\varepsilon \mathrm{Nd}$ values indicating a reduction of sediment from the Orange River and an increase of coarse sediment fom the coastal area. We note that despite a notable decrease of Orange River sediments and an increase of local sediment input, the former remains the most dominant source, and therefore the shift

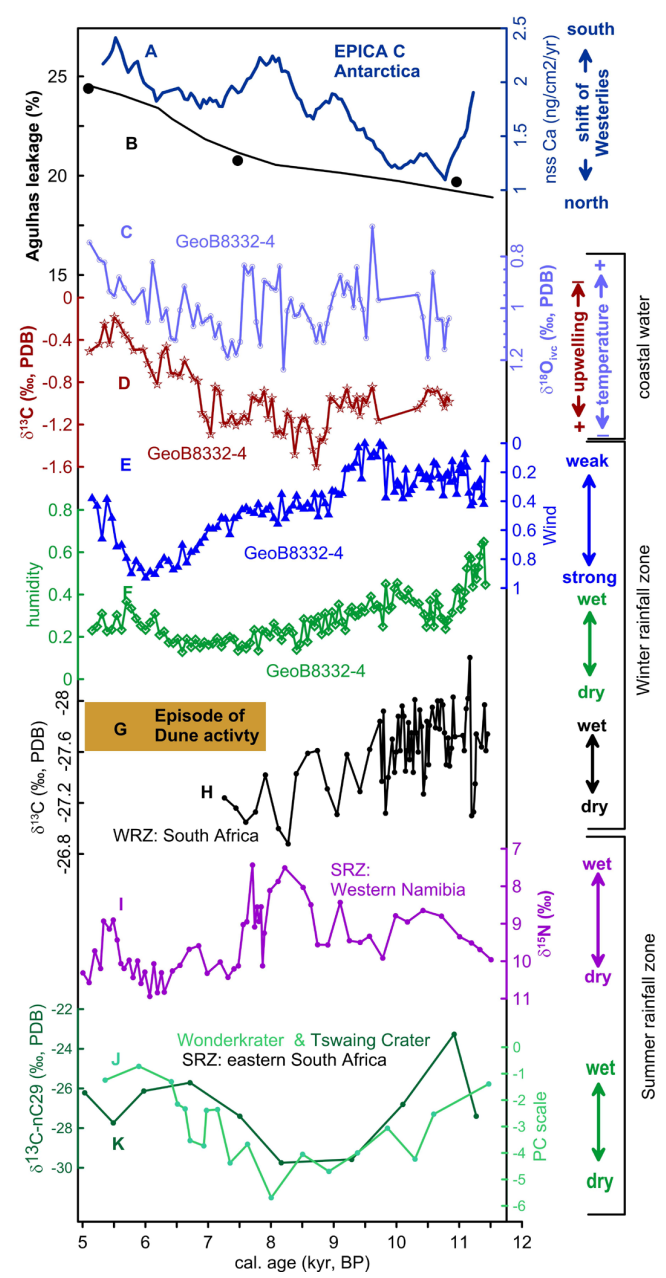

Fig. 6. Early and middle Holocene paleo-environmental proxies reconstructed from climate archives in southwestern Africa, eastern South Africa, and Antarctica. (A) 7-point running average of nss $\mathrm{Ca}^{2+}$ analyzed in EPICA Dome $\mathrm{C}$ ice core indicating variation of dust incursion over Antarctica in response to latitudinal shifts in the austral westerlies (Roethlisberger et al., 2002). (B) Estimate of Agulhas leakage into the South Atlantic (Peeters et al., 2004). (C) Ice-volume-corrected $\delta^{18} \mathrm{O}\left(\delta^{18} \mathrm{O}_{\mathrm{ivc}}\right)$ and (D) $\delta^{13} \mathrm{C}$ analyzed in $N$. pachyderma (sinistral) in core GeoB83324. (E) Wind strength ([EM1/EM1 + EM2]) and (F) humidity $([\mathrm{EM} 3 / \mathrm{EM} 1+\mathrm{EM} 2+\mathrm{EM} 3])$ indices inferred from grain size analysis and end-member modeling from the lithogenic fraction in GeoB8332-4. (G) Orange box indicates time interval (8-4 kyr BP) of enhanced dune activity in the coastal area of southwestern Africa (Chase and Thomas, 2006). (H) $\delta^{13} \mathrm{C}$ and (I) $\delta^{15} \mathrm{~N}$ analyzed in hyrax dung from the WRZ in South Africa (Chase et al., 2011) and the SRZ in western Namibia (Chase et al., 2009), respectively. (J) Relative moisture estimates based on principal component (PC) analysis of pollen time series from Wonderkrater (Scott el al., 2012). (K) $\delta^{13} \mathrm{C}$ signature of an $\mathrm{n}$-alkane (nC29: $\mathrm{n}$-alkane with $29 \mathrm{C}$ atoms) used as a biomarker for dominance of "C3" plants (Kristen et al., 2010). 
of the $\mathrm{Nd}$ isotope signature is small. In order assess the link between changes in the amount of sediment with Orange River eNd signature and climate conditions in the Orange River catchment, we compare our record with those from eastern South Africa where the main tributaries of the Orange River originate. Re-evaluations of several pollen records within the Orange River catchment and northeast of the catchment (Scott et al., 2008, 2012) suggest a heterogenous pattern between these closely located sites. The Braamhoek pollen record (within the Orange River catchment) suggests relatively wet conditions through the early Holocene with slight drying trend toward the mid-Holocene (Scott et al., 2012). A pollen record from the northeastern periphery of the Orange River basin (Rietvlei swamp) largely supports the climate trend as suggested by the Braamhoek pollen record (Scott et al., 2012). Farther northeast from the Orange basin, the early and mid-Holocene climate trend, as suggested by the Wonderkrater pollen record (Scott et al., 2012) and biomarker record from Tswaing Crater (Kristen et al., 2010), is markedly different from that of Braamhoek and Rietvlei records (Scott et al., 2012). The Wonderkrater (Scott et al., 2012) and Tswaing records (Kristen et al., 2010) suggest early Holocene (11 500-10 000 yr BP) humid conditions that gave way to mid-Holocene (9500-6500 yr BP) dry conditions (Fig. 6j and k). The comparison indicates that a link exists between humid climate conditions in eastern South Africa and an increase of fine components (EM3 and EM2) in the terrigenous sediment of Geo8332-4. Between 9500 and $7500 \mathrm{yr}$ BP, the decrease of mositure in eastern South Africa (Fig. 6j and k) parallels the decline of EM3. The onset of the humid climate conditions around 7500-7000 yr BP in eastern South Africa corresponds with increase of EM1, indicating relatively dry conditions in the coastal area.

The highest value of EM1, the end-member with the largest modal grain size of $20 \mu \mathrm{m}$, and more negative eNd value indicating a relatively enhanced eolian contribution from Namaqualand occurred at the time (7500-5000 yr BP) when humid climate conditions were established in eastern South Africa (Fig. 4d). Increase in dust input, most likely due to strengthened or more frequent easterly winds, was accompanied by a continuous weakening of coastal upwelling and surface water warming, as suggested by the $\delta^{13} \mathrm{C}$ and $\delta^{18} \mathrm{O}$ records (Fig. $6 \mathrm{c}$ and d). As discussed above, and consistent with the conceptual climate model of Cockcroft el al. (1987), we note that during the mid-Holocene a clear asymmetry exists between wet-dry patterns in the WRZ of South Africa and the main catchment of the Orange River in eastern South Africa. Cockcroft et al. (1987) postulated that during a dry phase in the WRZ near-surface southeasterly (equatorward) winds prevail along the coastal region of $\mathrm{Na}-$ maqualand that would strengthen the southern BUS. During the mid-Holocene dry phase our record indicates, however, a weakening of the southern BUS and warming of the surface water. We note that an increased Agulhas leakage is recorded concurrent with the mid-Holocene upwelling decline and surface warming. Analagous with modern observations in the southern BUS (Hardman-Mountford et al., 2003; Biastoch et al., 2009; Lutjeharms et al., 2001), we suggest that an enhanced leakage of warm water into the eastern South Atlantic changes the thermal and density structure of seawater along the west coast and weakens upwelling (see discussion below). The question remains open whether the midHolocene weakening of the southern BUS, as strongly indicated by our record, occurred despite the prevalence of southeasterly winds or concomitant with a weakening of southeasterly winds.

Comparison of our results with available terrestrial records in the WRZ in South Africa reveals a broadly consistent pattern of regional climate variability. Between 12000 and 9500 cal years BP pollen time series as well as carbon and nitrogen isotope records from the western margin of the WRZ (Scott and Woodborne, 2007b, a) reveal a dominance of pollen assemblages and isotope signatures indicative of enhanced moisture availability. At $\sim 8500$ cal years BP, the relatively wet conditions gave way to a more arid environment that persisted until $5600 \mathrm{cal}$ years BP. The onset of aridification, as recorded in the pollen data, is coincident with the increase of coarse terrigenous material in our record, supporting our interpretation that the increase in coarse particles reflects dust mobilization under arid climates. Farther to the south within the WRZ, a ${ }^{13} \mathrm{C}$ time series analyzed in hyrax dung also suggests early Holocene wet conditions and gradual climate deterioration throughout the middle Holocene (Fig. 6h) (Chase et al., 2011). We note that there exists a multi-centennial mismatch pertaining to the onset and termination of the dry and wet phases, as reflected in the various records referred above. This mismatch could not only be related to age model uncertainties but could also arise due to the elevation and the relative proximity of the hyrax dung collection sites to the perennial rainfall zone and/or summer rainfall zone (SRZ). Similarly, there exists a mismatch between the onset and termination in the strength of northeasterly and easterly winds in our record and those of dune mobilization in the coastal area (Chase and Thomas, 2006). The timing of enhanced middle Holocene dune activity along the west coast of South Africa has been constrained between 4000 and 8000 cal years BP (Fig. 6g) (Chase and Thomas, 2006). Our records of dust and fluvial sedimentation indicate that the timing of dune activity in Namaqualand overlaps to a large extent with the episode of enhanced wind strength (9000-5500 cal years BP). Chase and Thomas (2006) note that their age model most likely reflects the cessation of a dune activity rather than the onset of dune mobility. Hence, it is very likely that the onset of arid conditions, as suggested by our records, and dune mobility in Namaqualand (Chase and Thomas, 2006) are temporally coincident and that the invigoration of the northeasterly and easterly winds was most likely critical for the dune formation. The overall picture that emerges from this comparison is a broadly consistent pattern of paleo-environmental conditions in the WRZ of southwestern Africa with wet conditions 
during the early Holocene between 11500 and $9100 \mathrm{cal}$ years BP and an aridification trend, gradual weakening of the southern BUS, and surface water warming of coastal water between 9000 and 5000 cal years BP.

Comparing our records with terrestrial counterparts from the southwestern African SRZ (Chase et al., 2010, 2009) and marine records off Southwestern Africa (Shi et al., 2000; Stuut et al., 2002; Stuut and Lamy, 2004), it is evident that both climate regimes indicate a trend of gradual aridification throughout the early to middle Holocene (Fig. 6e and f). On millennial and sub-millennial scales, however, there exists a significant deviation, as indicated by the return of the SRZ to humid conditions between 8700 and $7500 \mathrm{yr}$ BP (Fig. 6e) (Chase et al., 2009) and intensification of dust mobilization between 9000 and $5500 \mathrm{yr}$ BP in the WRZ, as suggested by our record. Extending the comparison of our record to those of mid-latitude South America, we note several common features. Relatively humid conditions during the early Holocene (11.5-9500 $\pm 500 \mathrm{yr}$ BP) and late middle Holocene centered at $5000 \pm 500 \mathrm{yr}$ BP across southwestern Africa (Fig. 6e and h) have their counterparts in southern South America, as indicated by rise in lake levels (Stine and Stine, 1990), dominance of moisture-indicating pollen assemblages (Moreno et al., 2010), and advance of mountain glaciers (Douglass et al., 2005). All these records suggest enhanced moisture availability, most likely in response to large-scale changes in atmospheric circulation. Key atmospheric features that exert control on the Southern Hemisphere mid-latitude moisture distribution are the westerly winds. Conceptual models emphasize that changes in the strength and latitudinal shift of the southern westerlies and attendant subtropical disturbances could have played a critical role in shaping past precipitation in southwestern Africa and mid-latitude South America (Cockcroft et al., 1987; Toggweiler and Lea, 2011; Toggweiler et al., 2006; Tyson et al., 2002). Millennial- and orbital-scale climate variability in subtropical and temperate latitudes has been also linked to latitudinal shifts of the southern westerlies (Lamy et al., 2007, 2011; Moreno et al., 2010; Stuut and Lamy, 2004).

A crucial observation in our record that infers the most probable climate link and mechanism is the coupling between aridification, weakening of the southern BUS, and surface water warming (Fig. 6). Over the same period, proxy records indicate an increase of Agulhas water leakage into eastern South Atlantic (Peeters et al., 2004) and rise of non-sea-salt (nss) $\mathrm{Ca}^{2+}$ accumulation in Antarctic ice cores (Roethlisberger et al., 2002) (Fig. 6a and b). Long-term change in nss $\mathrm{Ca}^{2+}$ over Antarctica is thought to reflect changes in dust sources (vegetation cover and soil moisture) and changes in atmopheric circulation (Dixon et al., 2012; Roethlisberger et al., 2002). Time series analyses show that a dramatic increase of nss $\mathrm{Ca}^{2+}$ accumulation rate in West Antarctica ice cores over the last 4 decades of the last century is linked to an intensification (Dixon et al., 2012) and a southward shift of the austral westerlies in the Atlantic and Indian Ocean sectors (Beal et al., 2011). Instrumental and modeling studies demonstrate that southward displacement of the austral westerlies and attendant southward shift of the subtropical front enable an increased leakage of warm and saline Agulhas water into the South Atlantic (Beal et al., 2011; Biastoch et al., 2008, 2009; Shannon et al., 1990). Modern observations also show that the incursion of Agulhas water into the southern BUS warms the surface water and weakens the coastal upwelling due to changes in the density structure of surface water (Hardman-Mountford et al., 2003; Biastoch et al., 2009; Lutjeharms et al., 2001). Rainfall observations in the WRZ between 1950 and 1999 show that with exception of the central area winter rainfall declined significantly in the south, in the north, and inland of the WRZ of Namaqualand (MacKellar et al., 2007). Overall, instrumental observations of the last 4-5 decades of the last century show that there is a clear temporal coincidence and most likely causal links between southward displacement of austral westerlies and subtropical front, enhanced Agulhas leakage, increase in nss $\mathrm{Ca}^{2+}$ accumulation over Antarctica, a weakening of the southern BUS, and decline of winter rainfall in large parts of Namaqualand. Therefore based on the links deduced from modern observations we suggest that the middle Holocene dry conditions in Namaqualand and the weakening of the southern BUS most likely were linked to a poleward shift of the austral westerlies and an enhanced amount of Agulhas water leakage, as indicated by geochemical analysis in Antarctic ice cores (Roethlisberger et al., 2002) and the shift in planktonic foraminiferal composition off South Africa (Peeters et al., 2004), respectively (Fig. 6a and b). Furthermore, we suggest that increased leakage of Agulhas water into the southern BUS and resultant warming of the coastal water during the middle Holocene may have reduced coastal fog formation. At present, coastal fog formation over the cold upwelled coastal water presents an important moisture source for the flora of Namaqualand (Cowling et al., 1999; MacKellar et al., 2007). Warming of the coastal water reduces the thermal gradient between air and surface water temperature and fog formation.

Stager et al. (2012) suggest that increase in nss $\mathrm{Ca}^{2}$ concentration in the Siple Dome ice core (western Antarctica) may be related to equatorward shift of the austral westerlies. While location, altitude, and accumulation rate of snow may complicate a meaningful comparison between the nss $\mathrm{Ca}^{2}$ record of Siple Dome and EPICA Dome C, we argue that centennial- and millennial-scale increase of nss $\mathrm{Ca}^{2+}$ in the EPICA ice core suggest a poleward shift of the austral westerlies. Our argument is based on mid-Holocene and modern observation. Modern observations over the last 4-5 decades show a temporal coincidence and causal link between dramatically increased nss $\mathrm{Ca}^{2+}$ over Antarctica (Dixon et al., 2012), southward displacement and strengthening of the austral westerlies (Beal et al, 2011), and weakening of the southern BUS (Hardmann-Mountford et al., 2003: Lutjeharms et al., 2001). Similarly, the mid-Holocene continous increase 
of nss $\mathrm{Ca}^{2+}$ along with enhanced Agulhas water leakages is more compatible with a poleward shift of the austral westerlies and associated subtropical front (Fig. 6).

\subsection{Climate trend in southwestern Africa during the "Little Ice Age"}

Over the last $700 \mathrm{yr}$, the GeoB8332-4 is marked by a gradual increase of fine-grained fluvial sediment (EM3). $\mathrm{Nd}$ and $\mathrm{Sr}$ isotope analyses suggest that ephemeral rivers of Namaqualand and probably tributaries of the Lower Orange River significantly contributed to the continuous rise of fluvial sediments between 600 and $100 \mathrm{cal}$ years BP (Fig. 4c and d). Robust climate records from the main catchment of the Orange River covering the last $700 \mathrm{yr}$ are rare. $\delta^{18} \mathrm{O}$ records of cave deposits in the Makapansgat Valley have been interpreted to reflect cold and relatively dry conditions (Tyson et al., 2000). Pollen in a sediment sequence from Lake Eteza located in easternmost South Africa (SRZ) indicates low tree percentages and an increase of grass accompanied by high sedimentation rate during the last $700 \mathrm{yr}$, and has been interpreted as reflecting dry conditions and anthropogenic impact (Neumann et al., 2010). The interpretation of dry climate in eastern South Africa is corroborated by measurements of tree ring thickness suggesting two prolonged dry phases within the last $700 \mathrm{yr}$ (Vogel et al., 2001). Overall, available records from eastern South Africa suggest that climate during the last $700 \mathrm{yr}$ was relatively dry. In contrast, an increasing flood occurrence in the banks of the Buffels River (Figs. 1 and $7 \mathrm{j}$ ) (Benito et al., 2011) and in the Lower Orange River (Herbert and Compton, 2007, and references therein) as well as pulses of freshening events evident in the Lake Verlorenvlei record (Stager et al., 2012) (Figs. 1 and 7k) over the last 700-600 yr lend credence to our $\mathrm{Nd}$ and $\mathrm{Sr}$ isotope-based inference of increased sediment contribution from the local rivers.

The increase in fluvial sediments of proximal origin between 600 and $100 \mathrm{yr}$ BP falls within the time interval of global climate instability known as the Little Ice Age (LIA). In the northern hemisphere, the duration of the LIA encompasses the time between 1300 and 1850 Common Era (CE) (Holzhauser et al., 2005; Miller et al., 2012). Elsewhere, the timing of the northern cold spell is less well constrained, due to dating uncertainties and interhemispheric difference in the onset and termination of this climatic event (Schaefer et al., 2009). While anthropogenic contribution to the enhanced sediment mobilization at least during the younger part of the time series cannot be ruled out, we argue that our record largely reflects a regional expression of the global climate event associated with the LIA. Our data suggest that the winter rainfall zone of South Africa experienced humid conditions over the last $600 \mathrm{yr}$. Considering age model uncertainties that can account for up to $\pm 100 \mathrm{yr}$, the onset of humid phase in the WRZ of southwestern Africa at $600 \pm 50 \mathrm{cal}$ years BP is coincident with the onset of the decrease in nss $\mathrm{Ca}^{2+}$ accumulation of Antarctic ice cores at $\sim 650$ cal years

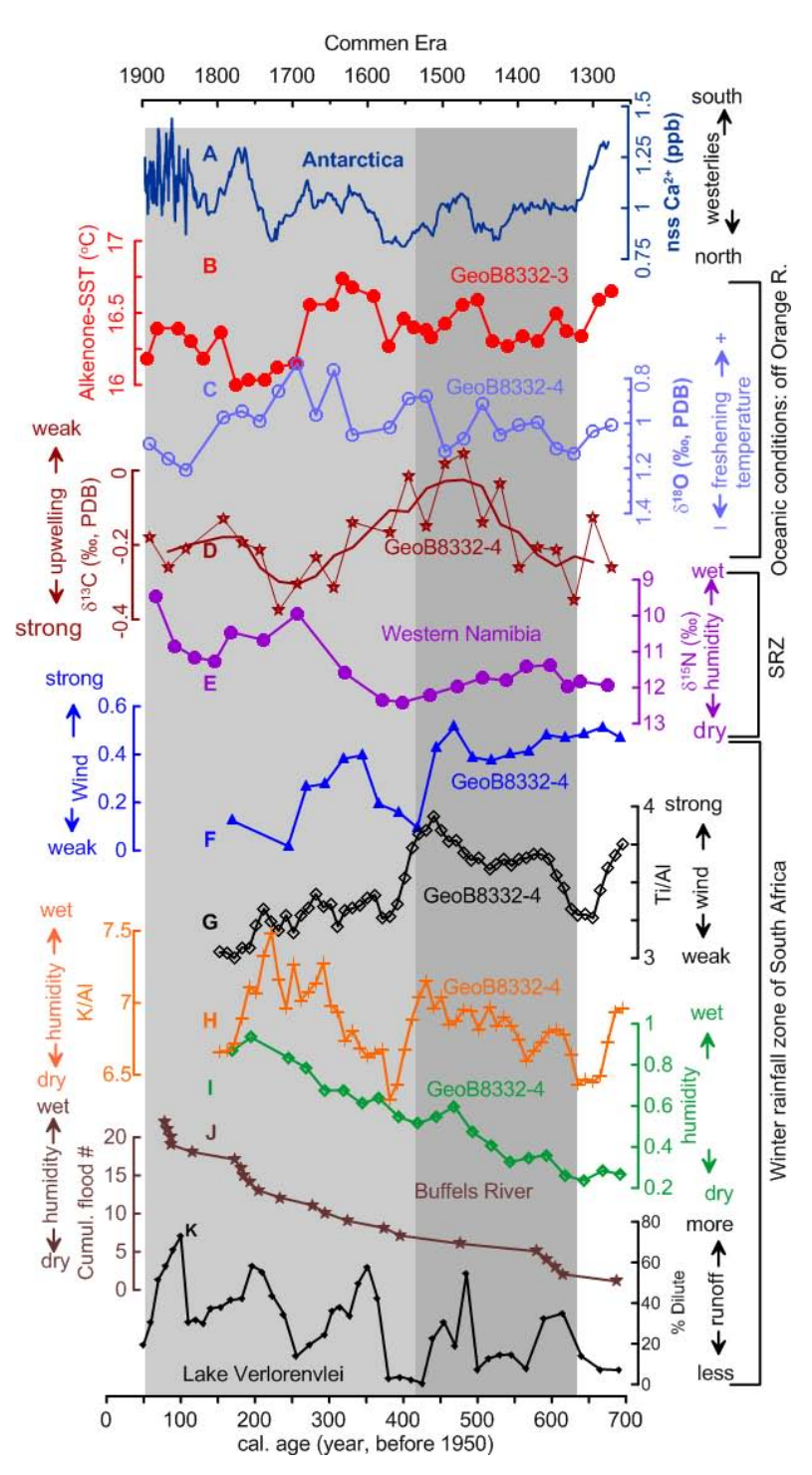

Fig. 7. Environmental conditions during the "Little Ice Age" in southwestern Africa. (A) 21-point running average of non-sea-salt $\mathrm{Ca}^{2+}\left(\mathrm{nss} \mathrm{Ca}{ }^{2+}=\mathrm{Na}-0.038 * \mathrm{Ca}^{2+}\right)$ analyzed in a Antarctic ice core (Siple Dome) (Kreutz and Mayewski, 1999). (B) Alkenonebased SST estimates off Holgat River analyzed in GeoB8332-3 (Leduc et al., 2010). Note that the locations of GeoB8332-3 and GeoB8332-4 are identical. (C) $\delta^{18} \mathrm{O}$ and (D) $\delta^{13} \mathrm{C}$ analyzed in $N$. pachyderma (sinistral) in core GeoB8332-4. (E) $\delta^{15} \mathrm{~N}$ analyzed in hyrax dung from the SRZ in western Namibia (Chase et al., 2009). (F) Wind strength inferred from grain size analyses and modeling in core GeoB8332-4. (G) Ti/Al and $(\mathbf{H}) \mathrm{K} / \mathrm{Al}$ analyzed in core GeoB8332-4. (I) Humidity index inferred from grain size analyses and modeling in core GeoB8332-4. (J) Cumulative flood number over the last 700 cal years BP reconstructed in Buffels River banks (Benito et al., 2011). (K) Percentage of diatom assemblages that are indicative for enhanced runoff in Lake Verlorenvlei (Stager et al., 2012). Dark gray area indicates time interval when fluvial proxies suggest wet conditions, high dust input, and strong winds in the WRZ. Light gray area indicates episode of wet conditions in both WRZ and SRZ. 
BP (Fig. 7a). With the exception of multi-decadal increase between 200 and 150 cal years $\mathrm{BP}$, nss $\mathrm{Ca}^{2}$ concentration remained low between 650 and $100 \mathrm{cal}$ years BP. Therefore, the increase in precipitation within the WRZ was linked to a large-scale atmospheric reorganization in mid-latitudes of the Southern Hemisphere. The early onset of the relatively humid conditions in the WRZ is contrasted by high Ti/Al and coarse grain sizes (EM1) (Fig. 7f and g). This probably indicates that dust input remained relatively high until approximately $400 \mathrm{cal}$ years BP. We note that the dust source extends deep into the northern and western SRZ of southwestern Africa (Prospero et al., 2002; Stuut et al., 2002; Mahowald, 2006). We suggest that the $\mathrm{Ti} / \mathrm{Al}$ record harbors a significant imprint of the climate development in the SRZ. Consistent with our records of high Ti / Al and EM1, a $\delta^{15} \mathrm{~N}$ time series analyzed in hyrax dung located in the SRZ of western Namibia suggests relatively dry conditions (Chase et al., 2010; Fig. 7e). Approximately at the timing of the rapid $\mathrm{Ti} / \mathrm{Al}$ drop $\left(\sim 400\right.$ cal years BP), the $\delta^{15} \mathrm{~N}$ record (Chase et al., 2010) and reconstruction of flood deposits in northwestern Namibia (Heine, 2004) suggest an onset of an increasingly humid episode in the SRZ. This comparison reveals that the onset of relatively wet conditions in the southwestern African SRZ was delayed by $\sim 200$ yr relative to that of the WRZ. Progressive northward expansion of the relatively wet WRZ into the southwestern margin of the SRZ presents one possible explanation. An alternative explanation arises when the timing of maximum impact of the northern LIA is considered. Intensification of ice-cap growth in the Canadian Arctic (Miller et al., 2012), maximal glacier advances in Europe (Holzhauser et al., 2005), and a significantly reduced meridional heat transport to the North Atlantic (Lund and Curry, 2006) commenced between 400 and $450 \mathrm{cal}$ years BP. As a consequence, an increased temperature gradient between the northern mid-latitudes and the tropics caused a large-scale southward displacement of the ITCZ, as suggested by the Lake Malawi and Cariaco Basin records (Haug et al., 2001; Johnson et al., 2001). Accordingly, the alternative hypothesis could be that at $400-450$ cal years BP a southward displacement of the intertropical convergence zone (ITCZ) during the austral summer allowed more moisture incursion into the arid SRZ in southwestern Africa.

Changes in oceanic conditions off the Orange River are inferred using the $\delta^{13} \mathrm{C}$ and $\delta^{18} \mathrm{O}$ records analyzed in tests of Neogloboquadrina pachyderma (sinistral) and alkenonebased SST estimates (Leduc et al., 2010; Meisel et al., 2011) (Fig. 7b-c). On the multi-centennial scale, the $\delta^{13} \mathrm{C}$ record indicates that between 700 and $\sim 550$ cal years BP the southern BUS was relatively strong. After a brief weakening (between 550 and 450 cal years BP) the invigoration of the southern BUS resumed at $\sim 450 \mathrm{yr}$ BP. Considering age model uncertainties, changes in SST estimates by Leduc et al. (2010) are consistent with the rise and decline of upwelling intensity, as inferred from the $\delta^{13} \mathrm{C}$ record. The $\delta^{18} \mathrm{O}$ record, reflecting both changes in temperature and isotopic composition of seawater, show relatively low values between 300 and 150 cal years BP, when $\delta^{13} \mathrm{C}$ and SST records suggest intensified upwelling and cool surface waters. One way to reconcile this divergence is by invoking enhanced fresh water input. On the multi-centennial time scale, our comparison of oceanic and terrestrial climate proxies reveals a coherent pattern between declining SST, strong upwelling off the Orange River, and humid conditions in the winter rainfall zone of southwestern Africa, indicating a common underlying cause. The more northerly position of the austral midlatitude westerlies, as suggested by low nss $\mathrm{Ca}^{2+}$ accumulation rate in Antarctic ice cores (Dixon et al., 2012; Roethlisberger et al., 2002), may have facilitated relatively enhanced precipitation, reduced the amount of Agulhas leakage, and enhanced upwelling that is in line with persistently increased upwelling in our record. While our interpretation pertaining to the possible role of the westerlies during the LIA is consistent with those of Stager et al. (2012), our record provide additional evidence of oceanic imprints of equatorward shifts of the westerlies.

\section{Conclusions}

We present a climate record of southwestern Africa that provides detailed insights into terrestrial and oceanic environmental conditions (Figs. 6-7 and Table 3). Grain size analysis and end-member modeling accompanied by element ratios, as well as stable and radiogenic isotope measurements allow the reconstruction of dust mobilization, variations in coastal upwelling, and fluvial input from perennial and ephemeral rivers. Our proxies indicate that during the middle Holocene the WRZ was marked by a continuous aridification that reached its height at around 5500 cal years BP. Increased dust deposition and weakening of the upwelling system are paralleled by a decreasing SE trade-wind intensity (Stuut et al., 2002; Stuut and Lamy, 2004) and enhanced leakage of warm Agulhas water (Peeters et al., 2004). We suggest that our mid-Holocene dust record reflects an intensification or more frequent incursion of easterly winds known as berg winds. The coincidence of local wind intensification and dune formation along the coastal area of northwestern South Africa (Chase and Thomas, 2006) may suggest a more prominent role of the northeasterly and easterly wind strength in the formation of the dunes.

Corroborating recent findings in sediment sequences of the Buffels River (Benito et al., 2011) and Lake Verlorenvlei (Stager et al., 2012), our study indicates that the coastal area of southwestern Africa experienced increasingly wet climate conditions during the last $600 \mathrm{cal}$ years BP. Furthermore, the multi-proxy record provides key hints as to how the SRZ climatically evolved during the LIA. The onset of relatively humid conditions in the SRZ lags by $\sim 200$ yr relative to that of the WRZ. The delayed onset corresponds to the timing of a significant weakening of heat export to the North Atlantic 
from the tropics (Lund and Curry, 2006) and a large-scale southward displacement of the ITCZ towards South Africa (Johnson et al., 2001; Haug et al., 2001). Hence, while a northward expansion of the humid WRZ into the arid SRZ cannot be ruled out, a southward shift of the ITCZ may have played a more dominant role in bringing more moisture to the SRZ.

The relatively wet phase in the WRZ during the Northern Hemisphere LIA shares many features in common with climate records of mid-latitude South America and New Zealand, most likely indicating a common cause. Climate models point to the critical role that a latitudinal shift of westerlies could have played in modulating past precipitation in the subtropical and mid-latitudes (Cockcroft et al., 1987; Toggweiler et al., 2006; Tyson et al., 2002). Our study provides evidence that the wet episodes in the coastal area of southwestern Africa were accompanied by relatively strong upwelling and cold surface waters. Conversely, the mid-Holocene gradual aridification trend was paralleled by a weakening of the southern BUS. These observations are consistent with a latitudinal shift of austral mid-latitude westerlies and varying amount of Agulhas water leakage into the southern BUS.

The findings of this study highlight the linkage between terrestrial climate in the coastal area and the variability of the southern BUS, and give us a better understanding of the southwestern Africa climate regime and its link to midlatitude atmospheric and ocean circulation. Based on the temporal and most likely causal relationship between the middle Holocene dry climate conditions in the WRZ, weakening of the southern BUS, increased leakage of warm Agulhas water, and poleward shifts of the austral mid-latitude westerlies, our findings lend strong support to the notion that in the context of global climate change southward shifts of the westerlies may result in a weakening of precipitation in the WRZ, and a decline in upwelling intensity, with implications for phytoplankton productivity and local fisheries. Furthermore, increasing leakage of Agulhas water as a result of the southward shift of the westerlies may cause further warming of the surface water and reduction of coastal fog formation.

Acknowledgements. We thank the Captain, Crew, and participants of Meteor cruise M57/1. We thank John Compton (University of Cape Town, South Africa) for providing a sediment sample from Alexander Bay, Holly Avery for help with stable isotope sample preparation, Gerrt-Jan Weltje for providing the End-Member Modeling Algorithm software, and Dorothy Pak for comments. We thank Stager and two anonymous reviewers for their insightful and constructive comments. We also thank Martin Claussen and Dominik Fleitmann for their editorial handling of this paper. $\mathrm{S}$. Weldeab is grateful to UCSB for a generous start-up package.

Edited by: D. Fleitmann

\section{References}

Bard, E., Hamelin, B., Arnold, M., Montaggioni, L., Cabioch, G., Faure, G., and Rougerie, F.: Deglacial sea-level record from Tahiti corals and the timing of global meltwater discharge, Nature, 382, 241-244, 1996.

Bayon, G., German, C. R., Nesbitt, R. W., Bertrand, P., and Schneider, R. R.: Increased input of circumpolar deep water-borne detritus to the glacial SE Atlantic Ocean, Geochem. Geophys. Geosys., 4, 1025, doi:1010.1029/2002GC000371, 2003.

Beal, L. M., De Ruijter, W. P. M., Biastoch, A., and Zahn, R.: On the role of the Agulhas system in ocean circulation and climate, Nature, 472, 429-436, 2011.

Bemis, B. E., Spero, H., Bijma, J., and Lea, D. W.: Reevaluation of oxygen isotope composition of planktonic foraminifera: experimental results and revised paleotemperature equations, Paleoceanography, 13, 150-160, 1998.

Benito, G., Thorndycraft, V. R., Rico, M. T., Sanchez-Moya, Y., Sopena, A., Botero, B. A., Machado, M. J., Davis, M., and Perez-Gonzalez, A.: Hydrological response of a dryland ephemeral river to southern African climatic variability during the last millennium, Quaternary Res., 75, 471-482, doi:10.1016/j.yqres.2011.01.004, 2011.

Biastoch, A., Boning, C. W., and Lutjeharms, J. R. E.: Agulhas leakage dynamics affects decadal variability in Atlantic overturning circulation, Nature, 456, 489-492, doi:10.1038/nature07426, 2008.

Biastoch, A., Boning, C. W., Schwarzkopf, F. U., and Lutjeharms, J. R. E.: Increase in Agulhas leakage due to poleward shift of Southern Hemisphere westerlies, Nature, 462, 495-498, doi:10.1038/nature08519, 2009.

Bremner, J. M., Rogers, J., and Willis, J. P.: Sedimentological aspects of the 1988 Orange River flods, Trans. Roy. Soc. South Africa, 47, 247-294, 1990.

Chase, B. M. and Meadows, M. E.: Late Quaternary dynamics of southern Africa's winter rainfall zone, Earth-Sci. Rev., 84, 103138, 2007.

Chase, B. M. and Thomas, D. S. G.: Late Quaternary dune accumulation along the western margin of South Africa: distinguishing forcing mechanisms through the analysis of migratory dune forms, Earth Planet. Sci. Lett., 251, 318-333, doi:10.1016/j.eps1.2006.09.017, 2006.

Chase, B. M. and Thomas, D. S. G.: Multiphase late Quaternary aeolian sediment accumulation in western South Africa: Timing and relationship to palaeoclimatic changes inferred from the marine record, Quaternary Int., 166, 29-41, 2007.

Chase, B. M., Meadows, M. E., Scott, L., Thomas, D. S. G., Marais, E., Sealy, J., and Reimer, P. J.: A record of rapid Holocene climate change preserved in hyrax middens from southwestern Africa, Geology, 37, 703-706, doi:10.1130/g30053a.1, 2009.

Chase, B. M., Meadows, M. E., Carr, A. S., and Reimer, P. J.: Evidence for progressive Holocene aridification in southern Africa recorded in Namibian hyrax middens: Implications for African Monsoon dynamics and the "African Humid Period", Quaternary Res., 74, 36-45, doi:10.1016/j.yqres.2010.04.006, 2010.

Chase, B. M., Quick, L. J., Meadows, M. E., Scott, L., Thomas, D. S. G., and Reimer, P. J.: Late glacial interhemispheric climate dynamics revealed in South African hyrax middens, Geology, 39, 19-22, doi:10.1130/g31129.1, 2011. 
Cockcroft, M. J., Wilkinson, M. J., and Tyson, P. D.: The application of a present-day climatic model to the late quaternary in southern Africa, Clim. Change, 10, 161-181, doi:10.1007/bf00140253, 1987.

Compton, J., Herbert, C., and Schneider, R.: Organic-rich mud on the western margin of southern Africa: Nutrient source to the Southern Ocean?, Global Biogeochem. Cy., 23, Gb4030, doi:10.1029/2008gb003427, 2009.

Compton, J. S.: Holocene sea-level fluctuations inferred from the evolution of depositional environments of the southern Langebaan Lagoon salt marsh, South Africa, The Holocene, 11, 395405, doi:10.1191/095968301678302832, 2001.

Compton, J. S. and Maake, L.: Source of the suspended load of the upper Orange River, South Africa, South Afr. J. Geol., 110, 339348, doi:10.2113/gssajg.110.2-3.339, 2007.

Compton, J. S., Herbert, C. T., Hoffman, M. T., Schneider, R. R., and Stuut, J.-B.: A tenfold increase in the Orange River mean Holocene mud flux: implications for soil erosion in South Africa, Holocene, 20, 115-122, doi:10.1177/0959683609348860, 2010.

Cowling, R. M., Esler, K. J., and Rundel, P. W.: Namaqualand, South Africa: An Overview of a Unique Winter-Rainfall Desert Ecosystem, Plant Ecol., 142, 3-21, 1999.

de Villiers, S., Compton, J. S., and Lavelle, M.: The strontium isotope systematics of the Orange River, Southern Africa, South Afr. J. Geol., 103, 237-248, doi:10.2113/1030237, 2000.

Dewar, G., Reimer, P. J., Sealy, J., and Woodborne ,S.: LateHolocene marine radiocarbon reservoir correction (Delta R) for the west coast of South Africa, Holocene, 22, 1481-1489, 2012

Dia, A., Allegre, C. J., and Erlank, A. J.: The development of continental crust through geological time: the South African case, Earth Planet. Sci. Lett., 98, 74-89, 1990.

Dixon, D. A., Mayewski, P. A., Goodwin, I. D., Marshall, G. J., Freeman, R., Maasch, K. A., and Sneed, S. B.: An ice-core proxy for northerly air mass incursions into West Antarctica, Int. J. Climatol., 32, 1455-1465, doi:10.1002/joc.2371, 2012.

Douglass, D. C., Singer, B. S., Kaplan, M. R., Ackert, R. P., Mickelson, D. M., and Caffee, M. W.: Evidence of early Holocene glacial advances in southern South America from cosmogenic surface-exposure dating, Geology, 33, 237-240, doi:10.1130/g21144.1, 2005.

Eisenhauer, A., Meyer, H., Rachold, V., Tuetken, T., Wiegand, B., Hansen, B. T., Spielhagen, R. F., Lindemann, F., and Kassens, H.: Grain size separation and sediment mixing in Arctic Ocean sediments: evidence from the strontium isotope systematic, Chem. Geol., 158, 173-188, 1999.

Govin, A., Holzwarth, U., Heslop, D., Ford Keeling, L., Zabel, M., Mulitza, S., Collins, J. A., and Chiessi, C. M.: Distribution of major elements in Atlantic surface sediments $\left(36^{\circ} \mathrm{N} \& 49^{\circ} \mathrm{S}\right)$ : Imprint of terrigenous input and continental weathering, Geochem. Geophys. Geosyst., 13, Q01013, doi:10.1029/2011gc003785, 2012.

Grousset, F., Biscaye, P. E., Revel, M., and Petit, J.-R.: Antarttic (Dome C) ice-core dust at 18 k.y. B.P.: Isotopic constraints on origins, Earth Planet. Sci. Lett., 111, 175-182, 1992.

Grousset, F. E. and Biscaye, P. E.: Tracing dust sources and transport patterns using $\mathrm{Sr}, \mathrm{Nd}$ and $\mathrm{Pb}$ isotopes, Chem. Geol., 222, 149-167, 2005.

Hardman-Mountford, N. J., Richardson, A. J., Agenbag, J. J., Hagen, E., Nykjaer, L., Shillington, F. A., and Villacastin,
C.: Ocean climate of the South East Atlantic observed from satellite data and wind models, Prog. Oceanogr., 59, 181-221, doi:10.1016/j.pocean.2003.10.001, 2003.

Haug, G. H., Hughen, K. A., Sigman, D. M., Peterson, L. C., and Röhl, U.: Southward migration of the Intertropical Convergence Zone through the Holocene, Science, 293, 1304-1308, 2001.

Heine, K.: Little Ice Age climatic fluctuations in the Namib Desert, Namibia, and adjacent areas: Evidence of exceptionally large floods from slack water deposits and desert soil sequences, in: Palecology of Quaternary Drylands, edited by: Smykatz-Kloss, W. and Felix-Henningsen, P., Lecture Notes in Earth Sciences, Springer-Verlag, Springer Berlin/Heidelberg, 137-165, 2004.

Herbert, C. T. and Compton, J. S.: Geochronology of Holocene sediments on the western margin of South Africa, South Afr. J. Geol., 110, 327-338, doi:10.2113/gssajg.110.2-3.327, 2007.

Holzhauser, H., Magny, M., and Zumbuhl, H. J.: Glacier and lakelevel variations in west-central Europe over the last 3500 years, Holocene, 15, 789-801, doi:10.1191/0959683605hl853ra, 2005.

Jacobson, S. B. and Wasserburg, G. J.: Sm-Nd isotopic evolution of chondrites, Earth Planet. Sci. Lett., 50, 139-155, 1980.

Johnson, T. C., Barry, S. L., Chan, Y., and Wilkinson, P.: Decadal record of climate variability spanning the past $700 \mathrm{yr}$ in the southern Tropics of East Africa, Geology, 29, 83-86, doi:10.1130/0091-7613(2001)029<0083:drocvs>2.0.co;2, 2001.

Kristen, I., Wilkes, H., Vieth, A., Zink, K. G., Plessen, B., Thorpe, J., Patridge, T., and Oberhänsli, H.: Biomarker and stable carbon isotope analyses of sedimentary organic matter from Lake Tswaing: evidence for deglacial wetness and early Holocene drought from South Africa, J. Paleolimnol., 44, 143160, doi:10.1007/s10933-009-9393-9, 2010.

Lamy, F., Kaiser, J., Arz, H. W., Hebbeln, D., Ninnemann, U., Timm, O., Timmermann, A., and Toggweiler, J. R.: Modulation of the bipolar seesaw in the southeast pacific during Termination 1, Earth Planet. Sci. Lett., 259, 400-413, doi:10.1016/j.eps1.2007.04.040, 2007.

Lamy, F., Kilian, R., Arz, H. W., Francois, J.-P., Kaiser, J., Prange, M., and Steinke, T.: Holocene changes in the position and intensity of the southern westerly wind belt, Nat. Geosci., 3, 695-699, 2011.

Leduc, G., Herbert, C. T., Blanz, T., Martinez, P., and Schneider, R.: Contrasting evolution of sea surface temperature in the Benguela upwelling system under natural and anthropogenic climate forcings, Geophys. Res. Lett., 37, L20705, doi:10.1029/2010g1044353, 2010.

Locarnini, R. A., Mishonov, A. V., Antonov, J. I., Boyer, T. P., and Garcia, H. E.: World Volume 2: Temperature, in: NOAA Atlas NESDIS 69, edited by: Levitus, S., US Government Printing Office, Washington, D.C., 182 pp., 2010.

Lund, D. C. and Curry, W.: Florida Current surface temperature and salinity variability during the last millennium, Paleoceanography, 21, PA2009, doi:2010.1029/2005PA001218, 2006.

Lutjeharms, J. R. E., Monteiro, P. M. S., Tyson, P. D., and Obura, D.: The oceans around southern Africa and regional effects of global change, South Afr. J. Sci., 97, 119-130, 2001.

Mabote, M. E., Rogers, J., and Meadows, M. E.: Sedimentology of terrigenous mud from the orange river delta and the inner shelf off Namaqualand, South Africa, South Afr. Geogr. J., special edition, 108-114, 1997. 
MacKellar, N. C., Hewitson, B. C., and Tadross, M. A.: Namaqualand's climate: Recent historical changes and future scenarios, J. Arid Environ., 70, 604-614, 2007.

Mahowald, N. M., Baker, A. R., Bergametti, G., Brooks, N., Duce, R. A., Jickells, T. D., Kubilay, N. n., Prospero, J. M., and Tegen, I.: Atmospheric global dust cycle and iron inputs to the ocean, Global Biogeochem. Cy., 19, GB4025, doi:10.1029/2004gb002402, 2005.

Meadows, M. E. and Sugden, J. M.: A vegetation history of the last 14,000 years on the Cederberg, South-Western Cape Province, South Afr. J. Sci., 87, 34-43, 1991.

Meadows, M. E., Rogers, J., Lee-Thorp, J. A., Bateman, M. D., and Dingle, R. V.: Holocene geochronology of a continentalshelf mudbelt off southwestern Africa, The Holocene, 12, 59-67, doi:10.1191/0959683602hl521rp, 2002.

Meadows, M. E., Chase, B. M., and Seliane, M.: Holocene palaeoenvironments of the Cederberg and Swartruggens mountains, Western Cape, South Africa: Pollen and stable isotope evidence from hyrax dung middens, J. Arid Environ., 74, 786-793, doi:10.1016/j.jaridenv.2009.04.020, 2010.

Meisel, S., Struck, U., and Emeis, K.-C.: Nutrient dynamics and oceanographic features in the central Namibian upwelling region as reflected in delta(15)N-signals of suspended matter and surface sediments, Fossil Record, 14, 153-169, doi:10.1002/mmng.201100005, 2011.

Meyer, I., Davies, G. R., and Stuut, J.-B. W.: Grain size control on $\mathrm{Sr}-\mathrm{Nd}$ isotope provenance studies and impact on paleoclimate reconstructions: An example from deep-sea sediments offshore NW Africa, Geochem. Geophys. Geosys., 12, Q03005, doi:10.1029/2010gc003355, 2011.

Miller, G. H., Geirsdottir, A., Zhong, Y., Larsen, D. J., OttoBliesner, B. L., Holland, M. M., Bailey, D. A., Refsnider, K. A., Lehman, S. J., Southon, J. R., Anderson, C., Björnsson, H., and Thordarson, T.: Abrupt onset of the Little Ice Age triggered by volcanism and sustained by sea-ice/ocean feedbacks, Geophs. Res. Lett., 39, L02708, doi:10.1029/2011GL050168 2012.

Moreno, P. I., Francois, J. P., Moy, C. M., and Villa-Martinez, R.: Covariability of the Southern Westerlies and atmospheric $\mathrm{CO}_{2}$ during the Holocene, Geology, 38, 727-730, doi:10.1130/g30962.1, 2010.

Neumann, F. H., Scott, L., Bousman, C. B., and van As, L.: A Holocene sequence of vegetation change at Lake Eteza, coastal KwaZulu-Natal, South Africa, Rev. Palaeobot. Palynol., 162, 3953, doi:10.1016/j.revpalbo.2010.05.001, 2010.

Peeters, F. J. C., Acheson, R., Brummer, G. J. A., de Ruijter, W. P. M., Schneider, R. R., Ganssen, G. M., Ufkes, E., and Kroon, D.: Vigorous exchange between the Indian and Atlantic oceans at the end of the past five glacial periods, Nature, 430, 661-665, doi:10.1038/nature02785, 2004.

Prins, M., Postma, G., and Weltje, G. J.: Controls on terrigenous sediment supply to the Arabian Sea during the late Quaternary: the Makran continental slope, Mar. Geol., 169, 351-371, doi:10.1016/s0025-3227(00)00087-6, 2000.

Prospero, J. M., Ginoux, P., Torres, O., Nicholson, S. E., and Gill, T. E.: Environmental characterization of global sources of atmospheric soil dust identified with the NIMBUS 7 Total Ozone Mapping Spectrometer (TOMS) absorbing aerosol product, Rev. Geophys., 40, 1002, doi:10.1029/2000rg000095, 2002.
Reimer, P. J., Baillie, M. G. L., Bard, E., Bayliss, A., Beck, J. W., Blackwell, P. G., Ramsey, C. B., Buck, C. E., Burr, G. S., Edwards, R. L., Friedrich, M., Grootes, P. M., Guilderson, T. P., Hajdas, I., Heaton, T. J., Hogg, A. G., Hughen, K. A., Kaiser, K. F., Kromer, B., McCormac, F. G., Manning, S. W., Reimer, R. W., Richards, D. A., Southon, J. R., Talamo, S., Turney, C. S. M., van der Plicht, J., and Weyhenmeye, C. E.: Intcal09 and Marine09 radiocarbon age calibration curves, 0-50,000 years cal BP, Radiocarbon, 51, 1111-1150, 2009.

Roethlisberger, R., Mulvaney, R., Wolff, E. W., Hutterli, M. A., Bigler, M., Sommer, S., and Jouzel, J.: Dust and sea salt variability in central East Antarctica (Dome C) over the last 45 kyrs and its implications for southern high-latitude climate, Geophys. Res. Lett., 29, 1963, doi:10.1029/2002gl015186, 2002.

Rogers, J. and Rau, A. J.: Surficial sediments of the wavedominated Orange River Delta and the adjacent continental margin off south-western Africa, Afr. J. Mar. Sci., 28, 511-524, doi:10.2989/18142320609504202, 2006.

Schaefer, J. M., Denton, G. H., Kaplan, M., Putnam, A., Finkel, R. C., Barrell, D. J. A., Andersen, B. G., Schwartz, R., Mackintosh, A., Chinn, T., and Schlüchter, C.: High-Frequency Holocene Glacier Fluctuations in New Zealand Differ from the Northern Signature, Science, 324, 622-625, doi:10.1126/science.1169312, 2009.

Schneider, R. R. and cruise participants: Report and preliminary results of METEOR Cruise M 57/1, Cape Town - Walvis Bay, 20 January 2003-08 February 2003, 123 pp., Bremen, 2003, Berichte, Fachbereich Geowissenschaften, Universität Bremen, No. 216, 1-51, 2003.

Scott, L. and Woodborne, S.: Vegetation history inferred from pollen in Late Quaternary faecal deposits (hyraceum) in the Cape winter-rain region and its bearing on past climates in South Africa, Quaternary Sci. Rev., 26, 941-953, doi:10.1016/j.quascirev.2006.12.012, 2007a.

Scott, L. and Woodborne, S.: Pollen analysis and dating of Late Quaternary faecal deposits (hyraceum) in the Cederberg, Western Cape, South Africa, Rev. Palaeobot. Palynol., 144, 123-134, doi:10.1016/j.revpalbo.2006.07.004, 2007b.

Scott, L., Holmgren, K., and Partridge, T. C.: Reconciliation of vegetation and climatic interpretations of pollen profiles and other regional records from the last 60 thousand years in the Savanna Biome of Southern Africa, Palaeogeogr. Palaeocli. Palaeoecol., 257, 198-206, 2008.

Scott, L., Neumann, F. H., Brook, G. A., Bousman, C. B., Norström, E., and Metwally, A. A.: Terrestrial fossil-pollen evidence of climate change during the last 26 thousand years in Southern Africa, Quaternary Sci. Rev., 32, 100-118, doi:10.1016/j.quascirev.2011.11.010, 2012.

Shannon, L. V. and Anderson, F. P.: Applications of satellite ocean colour imagery in the study of the Benguela Current System, The South African J. Photogr. Remote Sens. Cartogr., 13, 153-169, 1982.

Shannon, L. V., Agenbag, J. J., Walker, N. D., and Lutjeharms, J. R. E.: A major perturbation in the Agulhas retroflection area in 1986, Deep Sea Res. Part A., 37, 493-512, doi:10.1016/01980149(90)90021-m, 1990.

Shi, N., Dupont, L. M., Beug, H.-J. r., and Schneider, R.: Correlation between Vegetation in Southwestern Africa and Oceanic 
Upwelling in the Past 21,000 Years, Quaternary Res., 54, 72-80, 2000.

Stager, J. C., Mayewski, P. A., White, J. W. C., Chase, B. M., Neumann, F. H., Meadows, M. E., King, C. D., and Dixon, J. E.: Precipitation variability in the winter rainfall zone of South Africa during the last $1400 \mathrm{yr}$ linked to the austral westerlies, Clim. Past, 8, 877-887, doi:10.5194/cp-8-877-2012, 2012.

Stine, S. and Stine, M.: A record from Lake Cardiel Of climate change in southern South-America, Nature, 345, 705-708, doi:10.1038/345705a0, 1990.

Stuiver, M. and Reimer, P. J.: Extended 14C data-base and revised calib 3.0 C-14 age calibration program, Radiocarbon, 35, 215230, 1993.

Stuut, J.-B. W., Prins, M. A., Schneider, R. R., Weltje, G. J., Jansen, J. H. F., and Postma, G.: A 300-kyr record of aridity and wind strength in southwestern Africa: inferences from grain-size distributions of sediments on Walvis Ridge, SE Atlantic, Mar. Geol., 180, 221-233, 2002.

Stuut, J. B. W. and Lamy, F.: Climate variability at the southern boundaries of the Namib (Southwestern Africa) and Atacama (northern Chile) coastal deserts during the last 120,000 yr, Quaternary Res., 62, 301-309, doi:10.1016/j.yqres.2004.08.001, 2004.

Toggweiler, J. R., Russell, J. L., and Carson, S. R.: Midlatitude westerlies, atmospheric $\mathrm{CO}_{2}$, and climate change during the ice ages, Paleoceanography, 21, PA2005, doi:10.1029/2005PA001154, 2006.

Toggweiler, J. R. and Lea, D. W.: Temperature differences between the hemispheres and ice age climate variability, Paleoceanography, 25, PA2212, doi:10.1029/2009pa001758, 2011.
Tyson, P. D., Karlen, W., Holmgren, K., and Heiss, G. A.: The Little Ice Age and medieval warming in South Africa, South Afr. J. Sci., 96, 121-126, 2000.

Tyson, P. D., Lee-Thorp, J., Holmgren, K., and Thackeray, J. F.: Changing gradients of climate change in Southern Africa during the past millennium: Implications for population movements, Clim. Change, 52, 129-135, doi:10.1023/a:1013099104598, 2002.

Vogel, J. C., Fuls, A., and Visser, E.: Radiocarbon adjusments to the dendrochronology of a yellowwood tree, South Afr. J. Sci., 97, 164-166, 2001.

Weldeab, S., Emeis, K.-C., Hemleben, C., Schulz, H., and Vennemann, T. W.: Sr, Nd isotope composition of Late Pleistocene sapropels and non-sapropel sediments from the Eastern Mediterranean Sea: Implications for detrital influx and climatic conditions in the source areas, Geochim. Cosmochim. Ac., 66, 35853598, 2002a.

Weldeab, S., Emeis, K.-C., Hemleben, C., and Siebel, W.: Provenance of lithogenic surface sediments and path ways of riverine suspended matters in the Eastern Mediterranean Sea: Evidence from ${ }^{143} \mathrm{Nd} /{ }^{144} \mathrm{Nd}$ and ${ }^{87} \mathrm{Sr} /{ }^{86} \mathrm{Sr}$ ratios, Chem. Geol., 186, 139149, $2002 \mathrm{~b}$.

Weldeab, S., Frank, M., Stichel, T., Haley, B., and Sangen, M.: Spatio-temporal evolution of the West African monsoon during the last deglaciation, Geophys. Res. Lett., 38, L13703, doi:10.1029/2011gl047805, 2011.

Weltje, G. J.: End-member modeling of compositional data: Numerical-statistical algorithms for solving the explicit mixing problem, Math. Geol., 29, 503-549, doi:10.1007/bf02775085, 1997. 